\title{
Pensamento composicional dialógico de Cada ano sem Debussy: dez versos sobre o
}

Dialogical composition in the Cada ano sem Debussy: dez versos sobre o seu nome (Each year without Debussy: ten verses about his name)

Felipe Mendes de Vasconcelos ${ }^{1}$ Universidade Federal de Minas Gerais felipemendes21@gmail.com 


\section{Resumo}

Este artigo investiga as relações dialógicas presentes no processo composicional da peça orquestral Cada ano sem Debussy: dez versos sobre o seu nome (2019). Busca, à luz do dialogismo bakhtiniano, refletir sobre composição e os conceitos de enunciado e dialogismo musical. Apoiado em três conceitos de dialogismo (FIORIN, 2016) - constitutivo, mostrado e entre sujeitos -, examina como a peça musical pode ser enfocada sob essas perspectivas. Para isso, a análise ressalta a interatuação entre o material próprio e o de outrem empregados na composição. Conclui que, frente a um pensamento composicional dialógico, as propostas de Bakhtin podem ser ferramentas eficazes de investigação.

Palavras-chave: Dialogismo musical; Enunciado musical; Composição; Citação; Bakhtin.

\section{Abstract}

This paper investigates the dialogical relations present in the compositional process of the orchestral piece Cada ano sem Debussy: dez versos sobre o seu nome (2019). It aims reflect on composition and concepts of musical utterance and dialogism under the light of Bakhtinian ideas. Based on three notions of dialogism (FIORIN, 2016) - constitutive, displayed and among individuals -, it examines how the musical work can be approached under these perspectives. For this, the analysis highlights the interaction between the authorial material and those by other ones used in the composition. It concludes that Bakhtin's proposals can be effective tools of investigation in front of dialogical composition thinking.

Keywords: Musical dialogism; Musical utterances; Composition; Quotation; Bakhtin.

\footnotetext{
1 Doutor em Música pela UFMG (bolsista Capes) orientado pelo prof. dr. Oiliam Lanna e mestre em Música pela UFRGS (bolsista CNPq) orientado pelo prof. dr. Celso Chaves. Atuou como professor auxiliar na Fames e como professor substituto na UFMG. Primeiro lugar no Concurso Nacional de Composição "Guerra-Peixe: 100 anos". Primeiro lugar no " 4 Concurso Latinoamericano de Composición Electroacústica y Electrónica Gustavo Becerra Schmidt". Tem se dedicado à composição musical e à pesquisa em Música. Atualmente trabalha como regente e professor.
} 
Cada ano sem Debussy: dez versos sobre o seu nome é uma peça orquestral, composta em 2019 e estreada no mesmo ano. Ela foi iniciada em 2018, ano em que se comemorou o centenário de morte do compositor francês Claude-Achille Debussy. Esta obra entra para o rol das peças que prestam homenagem e procuram um diálogo explícito com outras obras e outros compositores. Esse processo composicional que evidencia a presença alheia em um enunciado musical individual enfatiza o que pode ser denominado dialogismo musical. É sobre este universo dialógico que o presente artigo pretende discorrer. Para isso, enfocaremos a obra Cada ano sem Debussy em seu estado relacional enfatizando suas referências a obras alheias.

\section{Referencial teórico}

O estudo das relações dialógicas, ou do dialogismo, foi um tema investigado e constantemente trabalhado por Mikhail Bakhtin, principalmente dentro dos domínios da linguagem verbal, e é a base para algumas teorias desenvolvidas (e ainda hoje em desenvolvimento) posteriormente no campo da linguística. Contudo, Bakhtin mesmo, em vários momentos, considera também a linguagem musical em seus comentários (BAKHTIN, 2011, 2014, 2016). Outros autores (KORSYN, 2001; CASSOTI, 2011; NASSIF; SHROENDER, 2019; PETRACCA, 2018, para mencionar alguns), já pelo lado da música, sustentam o dialogismo bakhtiniano como ferramenta eficaz para investigações e reflexões nas áreas musicais. Korsyn (2001, p. 58), por exemplo, ressalta que as críticas e ideias de Bakhtin para a linguagem verbal tem implicações profundas para a pesquisa em música.

Para Bakhtin, o dialogismo está em todo processo comunicacional e refere-se às relações de sentido que os enunciados estabelecem entre si, desde os passados (que já foram proferidos) aos futuros (que potencialmente poderão ser proferidos) (CHARAUDEAU; MAINGUENEAU, 2014, p.160). Bakhtin (2016, p.106) propõe que a palavra quer ser ouvida, entendida, respondida e mais uma vez responder à resposta e assim ad infinitum.

Como o enunciado verbal, para Bakhtin, não tem um tamanho predefinido - podendo ser compreendido desde um "olá" nas conversas cotidianas a um romance em vários volumes -, o enunciado musical, por conseguinte, compreende tanto uma peça inteira como partes de uma obra. Um enunciado é "o mínimo daquilo que se pode responder" (BAKHTIN, 2016, p.133). Trazendo para as terminologias musicais, uma frase, um acorde, um gesto ou mesmo uma nota, aliados aos contextos nos quais se inserem, podem ser considerados enunciados musicais, tanto quanto uma obra completa, desde que se possa compreendê-los em algum nível e tomar uma posição responsiva em relação a eles.

Quando pensamos no modo de funcionamento da música, podemos perceber o quanto esse dialogismo está presente. Também aqui os enunciados musicais são sempre respostas a outros enunciados que vieram antes e que, em algum momento, receberão respostas através de outros enunciados que virão depois. (NASSIF; SCHROEDER, 2019, p.9). 
José Luiz Fiorin (2016), em seu livro Introdução ao pensamento de Bakhtin, separa três conceitos de dialogismo na obra do pensador russo: o primeiro conceito diz respeito ao dialogismo constitutivo da linguagem, o segundo ao dialogismo mostrado e o terceiro ao dialogismo entre sujeitos.

Dialogismo constitutivo - Por mais criativos que sejamos dentro de uma linguagem, ela não nos pertence totalmente, nem se faz no momento, mas na trama dialógica. O enunciado surge da cadeia de infinitos enunciados, deste modo, sua forma e seu sentido estão atrelados aos enunciados de outrem. "São tantas as vozes incorporadas que muitas delas são ativas em nós sem que percebamos sua alteridade (na figura bakhtiniana, são palavras que perderam as aspas)" (FARACO, 2009, p.85). Sob essa perspectiva, não é possível esquivar-se do contato com o enunciado alheio. Valentin Volochínov, conhecido membro do Círculo de Bakhtin, afirma que, por mais monológico que pareça um enunciado, ele é um elemento indissolúvel da comunicação discursiva que está, em um sentido responsivo, atrelado a outros enunciados: "Todo enunciado, mesmo que seja escrito e finalizado, responde a algo e orienta-se para uma resposta. Ele é apenas um elo na cadeia ininterrupta de discursos verbais" (VOLOCHÍNOV, 2017, p.184). Para o autor, cada obra é uma continuação de obras antecessoras com as quais embate, polemiza com elas, as ratifica ou as nega, ao mesmo tempo em que espera por uma compreensão ativa e responsiva, antecipa respostas etc.

$\mathrm{Na}$ linguagem musical, podemos detectar traços de um dialogismo constitutivo nas escolhas composicionais que unem autores através de certas preferências ou abnegações em comum. Isto é, a obra nova surge como resposta às obras precedentes, quer em modo de concordância, quer em discordância, mesmo que o compositor não tenha refletido sobre isso. As decisões composicionais que acolhem certos idiomas e paradigmas enquanto evitam outros são traços dessa interlocução e interligação entre enunciados musicais. Deste modo, a incorporação do enunciado alheio é parte imanente da criação na linguagem musical (como na verbal) e engendra-se em uma cadeia de respostas, réplicas, tréplicas...

A discussão acerca do dialogismo constitutivo da linguagem musical abre caminho para se pensar em relação aos gêneros em música. $O$ estudo dos gêneros em música expõe o fio dialógico capaz de agrupar várias obras sob uma denominação comum (ópera, oratório, homenagem, sonata, jazz, rock etc.). André Hodeir (1970, p.12), apesar de apresentar algumas definições, coloca que a noção de gênero em música é bastante flexível. Uma das definições de Hodeir presume gênero como reunião numa mesma família das formas que têm entre si afinidades de caráter. Bakhtin (2016, p.12), ao expor seu conceito de gênero, não é mais categórico. Para ele, os gêneros do discurso são tipos relativamente estáveis de enunciados. "Ao dizer que os tipos são relativamente estáveis, Bakhtin está dando relevo, de um lado, à historicidade dos gêneros, e, de outro, à necessária imprecisão de suas características e fronteiras", conforme analisa Carlos Alberto Faraco (2009, p.127, grifo do autor).

O dialogismo constitutivo é o caminho que liga os diversos enunciados entre si, e que se revela de forma mais clara nos percursos dentro de um mesmo gênero. As várias 
tendências da música a partir do século XX são, nessa ótica, exemplos de gêneros do discurso musical, como: pontilhismo, espectralismo, minimalismo, nova complexidade, nova simplicidade etc., isto é, são tipos relativamente estáveis de enunciados agrupados por características e afinidades comuns entre eles.

Silvia Nassif e Jorge Luiz Schroeder (2011, p.142) formulam que os artistas são capazes de criar não apenas porque são "inspirados" ou conhecem as técnicas de uma linguagem, mas sobretudo porque dispõem de gêneros do discurso. Em outro momento (NASSIF; SCHROEDER, 2019, p.6), eles afirmam que, por mais criativos e pessoais que possam ser os enunciados e proferidos em situações diversas, a existência do gênero discursivo nos leva a nunca abandonar a dimensão social de toda fala humana. O gênero põe em evidência a natureza responsiva e dialógica da linguagem.

Dialogismo mostrado - "[...] neste caso, o dialogismo é uma forma composicional. São maneiras externas e visíveis de mostrar outras vozes no discurso" (FIORIN, 2016, p.37). Como a linguagem já é constitutivamente dialógica, o dialogismo mostrado funciona como uma maneira de potencializar a percepção dessa característica, ou seja, de fazer sensível a presença do enunciado alheio. De acordo com Fiorin, há duas formas de inserir o discurso do outro no enunciado verbal: uma, em que o discurso alheio é abertamente citado e nitidamente separado do discurso citante, é o que Bakhtin chama discurso objetivado (discurso direto, discurso indireto, discurso indireto livre); outra, em que o discurso é bivocal, internamente dialogizado, em que não há separação muito nítida entre o enunciado citante e o citado (paródia, estilização, polêmica etc.).

Pensando no âmbito musical, o dialogismo mostrado, normalmente, caracteriza-se pela intenção do compositor de que se perceba o enunciado alheio como participante do seu próprio enunciado. No ambiente da pesquisa em música, alguns autores têm se empenhado em descrever essas ações. Nesse sentido, podemos citar algumas terminologias como citação musical, paráfrase musical, paródia musical etc. No entanto, não existe homogeneidade entre esses autores.

Stefan Kostka dedica um capítulo de seu Materials and techniques of 20th century music (2006) para descrever os processos composicionais que lidam diretamente com o enunciado alheio. A esse capítulo ele denominou "importações e alusões" (imports and allusions). $O$ autor reconhece nesses termos as "influências externas que têm efeitos sobre a música do século XX" (KOSTKA, 2006, p.157). Essas influências podem vir do passado (neoclassicismo, citações), do presente (música folclórica, jazz) e da música "não familiar" (músicas de outras culturas).

David Cope (2005) apresenta também o termo alusão para abarcar um conjunto de procedimentos que lidam diretamente com a incorporação do material alheio (ou com o dialogismo mostrado, segundo a terminologia utilizada neste texto). Sua categorização parte dos seguintes tópicos: 1) citações (quotations); 2) paráfrases (paraphrases); 3) semelhanças (likenesses); 4) "estruturalidades" (frameworks) e 5) características em comum (commonalities).

Leonard Meyer, em Music, the arts, and ideas (1967), interessou-se em abordar a interpenetração da música do passado na música do presente como um caso intra- 
artístico (intra-artistic) (MEYER, 1994, p.194). Meyer distingue quatro maneiras de como as músicas de outras épocas podem ser usadas na atual: paráfrase (paraphrase), empréstimo (borrowing), simulação (simulation) e modelação (modeling).

Não é o propósito deste artigo entrar nos detalhes das definições terminológicas desses autores (nem de outros não mencionados ${ }^{2}$ ), mas, por ora, ressaltar que o dialogismo mostrado em música - que engloba todos esses casos apresentados - tem sido investigado, mesmo quando esta nomenclatura é empregada.

Dialogismo entre sujeitos - Na visão de Bakhtin, o outro deve ser visto como participante direto do enunciado individual. Como coloca Ricardo Petracca (2018, p.44), é da relação dialógica entre sujeitos que se tem um enunciado através do qual o sujeito se posiciona em relação à alteridade. "A alteridade define o ser humano, pois o outro é imprescindível para sua concepção: é impossível pensar o homem fora das relações que o ligam ao outro" (BARROS, 2007, p.25). Para Bakhtin, o sujeito não é assujeitado, ou seja, submisso às estruturas sociais, nem é uma subjetividade autônoma em relação à sociedade. Mesmo que seja na mais individual das enunciações, o indivíduo atua em relação aos outros (FIORIN, 2016, p.60). Cecília Almeida Salles (2014, p.152), que investiga os processos de criação artística, compartilha dessa noção da interação entre os homens:

\begin{abstract}
Os artistas - sujeitos construídos e situados - agem em meio à multiplicidade de interações e diálogos e encontram modos de manifestação em brechas que seus filtros mediadores conquistam. O próprio sujeito tem a forma de uma comunidade; a multiplicidade de interações não envolve absoluto apagamento do sujeito e o lócus da criatividade não é a imaginação do indivíduo. Surge, assim, um conceito de autoria, exatamente nessa interação entre o artista e os outros. É uma autoria distinguível, porém, não separável dos diálogos com o outro; não se trata de uma autoria fechada em um sujeito, mas não deixa de haver espaço de distinção. Sob esse ponto de vista, a autoria se estabelece nas relações, ou seja, nas interações que sustentam a rede, que vai se construindo ao longo do processo de criação.
\end{abstract}

O dialogismo entre sujeitos é um dos aspectos que contribui na legitimação de uma pesquisa focada na obra individual de um compositor como reflexo ou visão particular de uma coletividade. Como sustenta Franco Ferrarotti (1988), no momento em que se concebe o indivíduo como uma reapropriação singular do universo social e histórico que o rodeia, é possível conhecer o social a partir da especificidade irredutível da práxis individual. Em outras palavras, o compositor é um ser único tão somente porque responde às condições objetivas do diálogo social de maneira específica e interage com as vozes sociais de modo único (cf. FIORIN, 2016, p.64).

O processo criativo da obra Cada ano sem Debussy será abordado neste texto do ponto de vista desses três aspectos do dialogismo. 


\section{Relações dialógicas nas homenagens musicais}

Como foi apontado no preâmbulo deste texto, Cada ano sem Debussy: dez versos sobre o seu nome é uma obra em homenagem a Debussy. Suas raízes dialógicas tocam o gênero das obras que prestam algum tipo de tributo a um ilustre falecido, como os tombeaux franceses Le tombeau de Coperin (1917), de Maurice Ravel; Pièce pour le tombeau de Paul Dukas (1935), de Olivier Messiaen; as homenagens À R. - hommage à Ravel (1987), de lánnis Xenakis; Homenaje a Tárrega (1932), de Joaquín Turina; Hommage à Chopin (1947), de Heitor Villa-Lobos; as obras em memória de uma personalidade Rituel: in memoriam Maderna (1975), de Pierre Boulez; Prelude in memory of Dmitri Shostakovich (1975), de Alfred Schnittke, entre outros. Tais obras afloram o dialogismo em sua própria razão de ser, trazem o outro (o homenageado) para o âmago da escuta, e, para o ouvido analítico, o diálogo entre o compositor e o homenageado é um dos enfoques possíveis.

Ainda no âmbito das homenagens, podem ser destacadas aquelas obras que realizam alguma forma de transliteração das letras do nome do homenageado para notas musicais que são utilizadas como estrutura melódica/harmônica a construção da obra. Dentro desse repertório, evidencia-se um eixo de dialogismo constitutivo que liga as obras que fazem uso desse artifício. Talvez o exemplo mais difundido seja o tetracorde sobre o nome Bach, cujas letras correspondem à cifragem alemã para as notas Si bemol, Lá, Dó, Si:

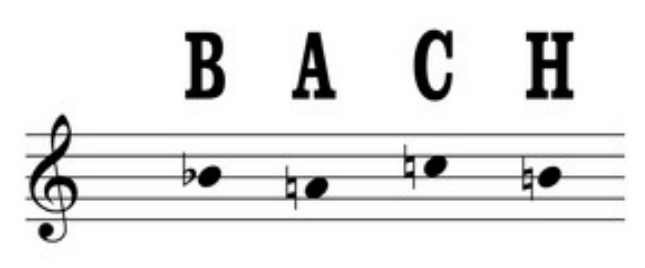

O próprio J. S. Bach fazia uma espécie de homenagem à sua linhagem. Como declara Ana Madalena Bach (1938, p.158) em suas memórias, Johann Sebastian tinha orgutho de ser um Bach e um de seus lazeres era colecionar escritos e composições dos diferentes membros da sua família: "[...] um Bach, com efeito, era sempre um musicista. As próprias letras do nome formam uma melodia, conforme Sebastian não deixava de fazer notar com satisfação". Além de Bach, outros compositores, nitidamente demonstrando apreço pela obra do grande gênio da música, utilizaram o tetracorde sobre o seu nome como material melódico: Franz Liszt (Präludium und Fuge über den Namen BACH), Nicolai Rimsky-Korsakov ( 6 Variations on the theme BACH), Anton Webern (Quartetos de cordas, op. 28) e Charles Koechlin (Offrande musicale sur le nom Bach) são apenas alguns deles.

Outro exemplo notável acontece em 1909, quando seis compositores franceses foram convidados pela Revue musicale mensuelle de la Société Internationale de Musique a escrever uma peça em homenagem a Joseph Haydn pela ocasião do centenário 
da morte do compositor: Ravel (Menuet sur le nom d'Haydn), Debussy (Hommage à Haydn), Vincent D'Indy (Menuet sur le nom d'Haydn), Paul Dukas (Prélude Élégiaque), Reynaldo Hahn (Theme varié sur le nom de Haydn) e Chales-Marie Widor (Fugue sur le nom d'Haydn). Todas essas obras contêm como principal material melódico/harmônico as cinco notas equivalentes às letras do nome de Haydn.

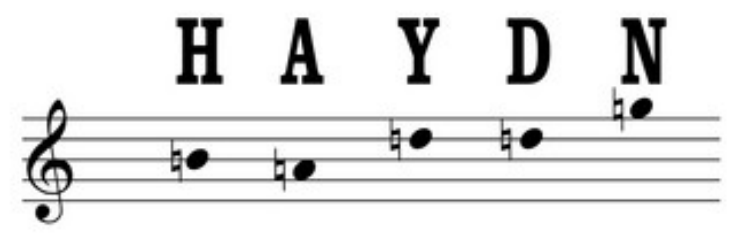

Caso semelhante são as doze obras em homenagem a Paul Sacher (1906-1999) comissionadas por Mstislav Rostropovich em comemoração aos setenta anos do maestro suíço. Os compositores convidados foram Luciano Berio, Conrad Beck, Pierre Boulez, Benjamin Britten, Henri Dutilleux, Wolfgang Fortner, Alberto Gisnatera, Cristóbal Halffter, Hans Werner Henze, Heinz Holliger, Klaus Huber e Witold Lutoslawsky. Todas as obras utilizam o hexacorde decorrente do nome de Sacher:

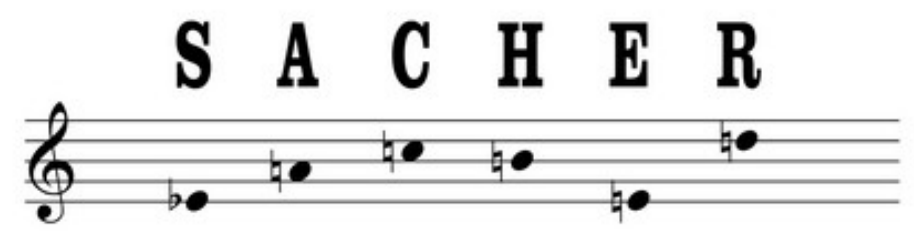

Boulez, por exemplo, parece ter se agradado desse conjunto de notas, e, além da obra Messagesquisse (1976-1977) - composta para esta encomenda de Rostropovich -, ele utiliza o hexacorde também em Répons (1981-1985), Dérive 1 (1984), Incises (1994/2001) e Sur Incises (1996/1998).

Uma das razões do panorama sobre essa espécie de criptografia musical - que é mais vasta que os exemplos aqui apresentados - é que, em Cada ano sem Debussy, esses nomes estão presentes e são "mencionados" musicalmente (falaremos a esse respeito mais adiante). A outra razão é que Cada ano sem Debussy também se refere ao seu homenageado por meio de uma sequência de notas:

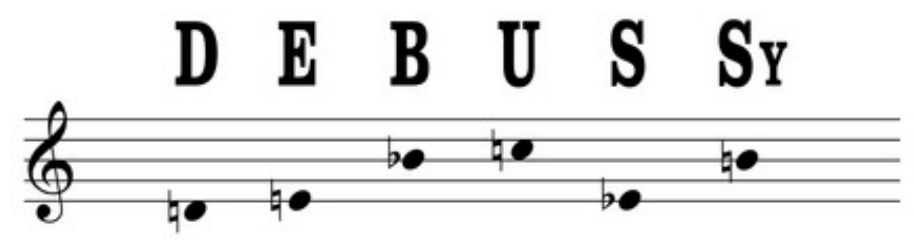


Foi utilizada a cifragem tradicional alemã para as letras "D" (Ré), "E" (Mi), "B" (Si bemol) e "S" (Mi bemol). Para a letra "U" foi utilizada a nota Dó, pensando na sua correspondente do idioma francês Ut. Para as letras restantes "S" e "Y" preferiu-se atribuir uma única nota: Si, por razão da sua fonética semelhante (Sy). O conjunto de notas decorrente do nome de Debussy é disposto melodicamente de várias maneiras, com várias combinações de ritmos, perfis e tessituras. Em alguns momentos, ele também é apresentado em forma de acorde, com suas notas simultâneas. (Alguns exemplos sobre a utilização do hexacorde DEBUSSy serão apresentados oportunamente no decorrer deste texto.)

Cada peça dos exemplos mencionados acima dialoga umas com as outras. É possível estabelecer conexões dentro do gênero das homenagens. Além disso, essas obras são tipos de respostas que naturalmente encontram interlocução com os enunciados dos homenageados específicos em cada obra. Quer a composição nova tenha ou não relações explícitas com a poética do seu homenageado, a música deste é uma interlocução importante. Isto é, quando Debussy, por exemplo, escreve Hommage à Haydn (1909), a música do compositor austríaco faz parte do diálogo, mesmo que não haja semelhanças patentes com a peça que the presta o tributo. $O$ dialogismo constitutivo em música, assim como na linguagem verbal, evidencia uma linha sutil que conecta os mais dispersos enunciados através do uso comum a que a linguagem se dispõe. Ao mesmo tempo, uma obra pode se conectar a outra pelo que não está presente. Ou seja, o analista, ou mesmo o ouvinte comum, pode voltar sua atenção para o que ou quais características musicais de Haydn não estão na peça de Debussy, por exemplo. É sob esse ponto de vista que "um enunciado é sempre heterogêneo, pois revela duas posições, a sua e aquela em oposição à qual ele se constrói. Ele exibe seu direito e seu avesso" (FIORIN, 2016, p.27).

Um outro tipo significativo de homenagem dentro da linguagem musical é a apropriação do enunciado musical alheio em uma nova composição. É o que foi colocado acima como dialogismo mostrado em música. Nos estudos musicais podemos encontrar esse tipo de dialogismo ao longo da história da música ocidental, já observável nas inúmeras missas da Idade Média e da Renascença, que eram construídas sobre cantos gregorianos anteriores ou sobre linhas melódicas de missas de outros compositores. Destarte, há vários tipos de apropriações e diálogos entre enunciados musicais que perduram no pensamento composicional até os dias de hoje (NASCIMENTO, 2012, p.40-43).

A partir do século XX, porém, destaca-se com maior intensidade a apropriação do material alheio com a intencionalidade referencial. Um tipo de metalinguagem. Música referindo-se à música. Tais casos apresentam-se como um discurso objetivado no qual as fronteiras da voz alheia são demarcadas e nitidamente separam o material próprio do reportado. É aquilo que nos estudos musicais atuais tem-se utilizado o epíteto citação musical como termo genérico e abrangente para esse tipo de reutilização de materiais preexistentes. Esta é a opção de Guilherme Nascimento (2012, p.20), por exemplo, que prefere utilizar o termo [citação] para "toda e qualquer apropriação de um texto preexistente, seja pelo lado de mencionar ou transcrever um trecho (ato de citação propriamente dito), seja pela apropriação estilo, ideias, temas ou personagens". 
Sofia Gubaidulina (1998, p.451, grifo do autor), falando sobre o assunto, entende que "esta citação, ou o esforço para usar uma forma já existente como ponto de referência é uma característica básica do século XX". A compositora atribui esse fenômeno ao enorme fluxo de informações que bombardeiam os compositores desde o último século:

\begin{abstract}
Penso que, desse modo, pode-se explicar o significado de figuras como Charles Ives, Bernd Alois Zimmermann, Alfred Schnittke e Luciano Berio em nosso século. Por que isso acontece é uma questão séria e vale a pena pensar a respeito. $O$ fato é que todos tipos de obras tentam refletir a abundância de informações que nos rodeiam. No entanto, a relação com esse material familiar é diferente para cada compositor. Por um lado, poderia ser um paraíso perdido. Por outro lado, poderia ser uma relação de oposição, uma relação alienante e irônica com um texto familiar. Além disso, uma citação pode ser usada como um ponto de referência, uma referência com um significado definido, como uma palavra. (GUBAIDULINA, 1998, p.451, tradução nossa) $)^{3}$.
\end{abstract}

A própria compositora russa pode ser incluída na lista desses compositores que exploram os enunciados musicais de outrem. Seu Offertorium, concerto para violino e orquestra (1980) é um ótimo exemplo do uso do dialogismo mostrado em música. Nessa obra, Gubaidulina apropria-se do Tema do rei (comumente atribuído ao rei Frederico II) utilizado por Bach em sua Oferenda musical. No início da peça ela orquestra esse tema aos moldes da Klangfabernmelodie, procedimento semelhante ao de Webern em sua transcrição do Ricercare a seis vozes da Oferenda musical, de Bach. Segundo Jenna Smith (2010, p.40), trata-se de uma dupla homenagem que exalça dois dos compositores favoritos de Gubaidulina.

Em um novo contexto, o material apropriado pode reforçar um pensamento ou tomar um sentido bastante distinto do original. Em Offertorium, a compositora aproveita a temática da oferenda (oferta cerimonial) para incorporar sua concepção composicional religiosa baseada no sacrifício do Cristo (cf. GUBAIDULINA, 1998), embora a Oferenda de Bach não seja uma obra sacra. Por outro lado, quando Carl Orff, em Carmina Burana (1936), insinua cantos litúrgicos da fé católica (a salmodia gregoriana, por exemplo) ao musicar o poema Ego sum abbas, ele acentua o caráter paródico e a inversão de valores que o texto suscita. Ou seja, trata-se de uma representação do dialogismo mostrado em música através do discurso bivocal. Neste momento da obra, estão amalgamadas a voz de autoridade da igreja, devota aos santos no templo, parodiadas nas vozes dos beberrões da seita de Décio e "devotos" de Baco no ambiente da taberna (LANNA, 2002, p 81).

Um outro exemplo icônico do discurso bivocal em música é a peça Ein musikalischer Spass (1787) (Uma brincadeira musical), de W. A. Mozart. Nesta, o compositor realiza um tipo de comentário sarcástico (sem uso de palavras) sobre certos chavões e inabilidades de compositores menores do classicismo: condução de vozes inapropriadas,

3 Original: "I think that, in this way, one can explain the significance of figures like Charles Ives, Bernd Alois Zimmermann, Alfred Schnittke, and Luciano Berio in our century. Why this happens is a serious question and is worth thinking about. The fact is, all kinds of works attempt to reflect the abundance of information surrounding us. Yet the relationship to this familiar material is different for every composer. On the one hand it could be longing for a lost paradise. On the other hand it could be a relationship of opposition, an alienating, ironic relationship to a familiar text. Futhermore a quote can be used as a point of reference, a reference with a definite meaning, like a word" (GUBAIDULINA, 1998, p.451). 
cadências e repetições clichês, notação errada para instrumentos transpositores, entre outras peripécias debochativas. Embora não haja uma peça específica citada musicalmente (até onde temos conhecimento), trata-se de um discurso bivocal como qualquer ironia na linguagem verbal.

A ideia de música comentando música foi proposta também por Berio. Para o compositor italiano, o terceiro movimento da sua Sinfonia (1968) é o comentário mais aprofundado que ele poderia ter feito sobre a música de Gustav Mahler (BERIO, 1988, p.95), e, neste texto, é um dos exemplos mais emblemáticos do dialogismo mostrado em música e da prestação de tributo em música. Berio declara que essa terceira parte da Sinfonia é uma homenagem a Mahler, ao mesmo tempo em que é uma "polifonia de partículas da História" (BERIO, 2017, p.240).

Fazia tempo que eu queria explorar por dentro uma música do passado, uma exploração criadora que fosse ao mesmo tempo uma análise, um comentário e uma extensão do original fiel ao seu princípio (que se perde na noite dos tempos) de que para um compositor a melhor maneira de analisar e comentar alguma coisa é fazer algo utilizando os materiais daquilo que se pretende analisar e comentar. (BERIO, 1988, p.95).

Este tipo de dialogismo mostrado é parte substancial do pensamento composicional de Cada ano sem Debussy. Esta peça reúne uma porção de alusões e citações da obra de Debussy, mas também de outros compositores. Esses empréstimos musicais funcionam como flashes debussistas que iluminam de tempos em tempos certos trechos da peça, que chamam atenção e logo se apagam, ora se misturam às estruturas novas, ora se desprendem e se mostram mais nitidamente.

\section{Estrutura e forma de Cada ano sem Debussy}

Cada ano sem Debussy, dez versos sobre o seu nome é em movimento único e pode ser dividida em dez partes demarcadas pelas nove letras de ensaio (comumente não há letra para a primeira parte).

\begin{tabular}{|c|l|}
\hline Letra de ensaio & \multicolumn{1}{c|}{ Subtítulo da seção } \\
\hline- & ... Sob as cãs de linho \\
\hline A & ... Antes dos oceanos \\
\hline B & ... Brumas das noites eternas \\
\hline C & ... Cortejo e funeral de um fauno \\
\hline D & ... Druidas e seus jogos \\
\hline E & ... Esfinge de níquel \\
\hline F & ... Festejo dos ancestrais \\
\hline G & ... Grinaldas \\
\hline H & ... Herança das florestas \\
\hline I & ... Invocações \\
\hline
\end{tabular}

Quadro 1: Denominação das seções de Cada ano sem Debussy. 
Em uma espécie de acróstico com a ordem das letras do alfabeto, foram dados os subtítulos que, acreditamos, Debussy mesmo os poderia dar, pois têm relações com o mistério e com o místico, características normalmente legadas ao compositor e comuns em alguns dos seus próprios títulos de obras. A maioria desses subtítulos faz referência à obra de Debussy e ao jogo dialógico a que Cada ano sem Debussy se propõe. Ademais, eles são precedidos por reticências, ideia que também aparece nos Prelúdios para piano (1910/1913), de Debussy. No contexto dialógico proposto aqui, essas reticências evocam, além da obra debussista, todo um universo de enunciados que precede o momento, isto é, remetem à concepção bakhtiniana do dialogismo constitutivo da linguagem, contrária a qualquer produto surgente ex nihilo.

Esses subtítulos, em sua maioria, evocam relações temporais, colocam juntos passado, presente e futuro - por exemplo, ao mencionar as "cãs", "eternidade", "ancestrais", "druidas", "herança", "esfinge"... palavras que portam em seus significados alguma referência ao tempo. De certa forma, em Cada ano sem Debussy procura-se uma polifonia de materiais distintos, de características e de épocas diferentes. Em meio a criação, citações e alusões, interagem materiais novos com antigos, materiais próprios e de outrem.

Na visão de André Boucourechliev (1993, p.125), uma das principais contribuições de Debussy para a música moderna se dá no campo do tempo: “Debussy recria o tempo musical, no mesmo sentido em que abole a noção de desenvolvimento". Um aspecto diretamente afetado por essa revolução no tempo musical é a forma. O autor franco-búlgaro aponta nas obras do compositor francês uma "invenção permanente da forma, bem como uma rejeição da simetria e da repetição a longo prazo (mas não da repetição imediata da frase, da 'duplicação')" (BOUCOURECHLIEV, 1993, p.125). Paul Griffths (2011, p.9), comentando o Prélude à l'après-midi d'un faune (1894), constata que não há um desenvolvimento progressivo nessa obra; em vez disso, ela gera um efeito de improvisação. Neste sentido, Jeux (1912) é outro exemplo elucidador. Essa obra não segue preceitos formais tradicionais, mas está moldada imanentemente no fluxo contínuo das seções, que cria uma forma que se renova incessantemente - a forma é processo, e não mais resultado (SOCHA, 2008, p.99; BOUCOURECHLIEV, 1993, p.126). Por essa razão, Debussy, através dessa obra, abre novos caminhos para o desenvolvimento da forma na modernidade e, consequentemente, demanda novos meios de audição (BOULEZ, 2008, p.307).

Roy Howat (1986) concorda que a obra de Debussy diverge radicalmente das formas musicais convencionais. Ele procura investigar na obra do compositor as relações entre as seções através de proporções matemáticas, como a simetria bipartida, a série de Fibonacci e a razão áurea. O autor demonstra seu ponto tomando por exemplos várias peças de Debussy, como Spleen, das Ariettes oubliées (1887), onde essas proporções revelam momentos estruturais relevantes: 


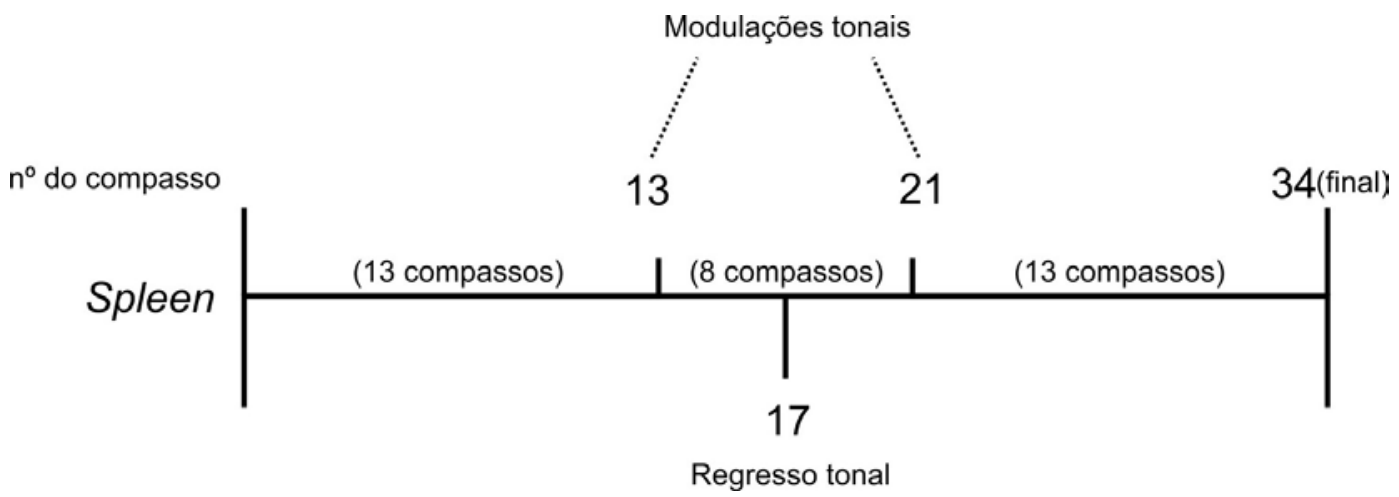

Nesse exemplo, é possível observar que as articulações principais se encontram em momentos correspondentes à seção áurea e utilizam números da série de Fibonacci $(8,13,21,34)$; além disso, o compasso [17] demarca o meio exato da peça.

Howat (2001, p.129) salienta que não é possível afirmar que Debussy tenha utilizado intencional e sistematicamente essas proporções matemáticas, pois o compositor não deixou registros do seu pensamento composicional e não costumava explicar suas técnicas. Antes, o autor aponta que é mais plausivel que Debussy tenha recorrido a um sentido puramente inconsciente de proporção.

Cada ano sem Debussy associa-se dialogicamente com a tendência formal erigida a partir de Jeux. Suas seções seguem um fluxo contínuo e não adotam nenhuma orientação estruturada segundo modelos clássicos da música ocidental. Porém, como Howat prevê, uma forma que parece se desenvolver intuitivamente não exclui a possibilidade de uma distribuição lógico-matemática das articulações, mesmo que o compositor não tenha refletido sobre isto. Neste contexto, tal situação reflete um elemento de uma linguagem assimilada, adquirida pelas vias invisíveis do dialogismo constitutivo musical.

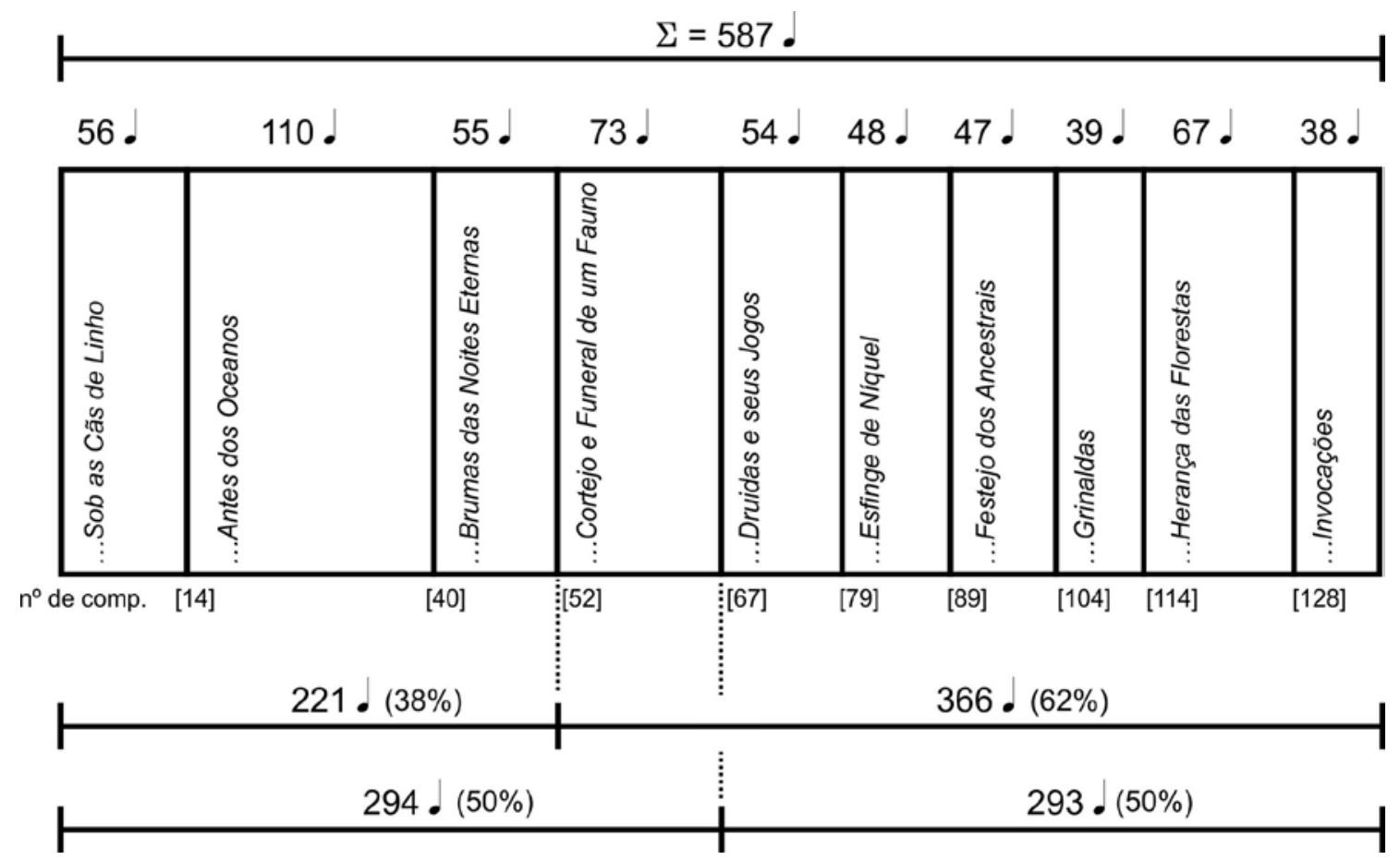


A principal articulação desta obra encontra-se na transição da seção demarcada pela letra B (... Brumas das noites eternas) - compassos [40-51] - para a seção demarcada com a letra C (... Cortejo e funeral de um fauno) - compassos [52-66]. A peça tem um total de quinhentos e oitenta e sete (587) tempos medidos em semínimas (figura base de todos os compassos da obra). O início do ... Cortejo e funeral de um fauno é localizado a aproximadamente trinta e oito por cento $(37,6 \%)$ da peça, isto é, há duzentos e vinte e um (221) tempos de semínimas antes desta seção. Isso corresponde a uma proporção próxima da razão áurea que seciona um todo em duas porções distribuídas em uma parte maior (cerca de 61,8\%) e uma parte menor (cerca de 38,2\%). Embora, geralmente, adote-se a maior porção da razão áurea para a primeira parte da peça musical, a inversão dessa ordem é também uma estratégia eficaz de proporcionalidade, como Howat $(1986,2001)$ ratifica diante da obra de Debussy.

No compasso [50] (penúltimo compasso de B) de Cada ano sem Debussy, destaca-se um acorde de Dó maior. Esse acorde surge após um acúmulo de dissonância e se destaca como oposição; não há ocorrência, nesta obra, de outro acorde perfeito maior tão devoluto. Como foi mencionado acima, a negação é uma categoria importante dentro do estudo das relações dialógicas, pois apresenta simultaneamente o enunciado negado e aquele que o nega. O acorde de Dó maior ao final de Polymorphia (1961), de Krzysztof Penderecki, seria também um exemplo desse tipo de relação. Nesses contextos, o acorde se comporta como um enunciado musical completo.

Durante toda a seção ... Brumas das noites eternas evoca-se a atmosfera noturna e o seu título faz referência aos Nocturnes (1899), para orquestra, de Debussy. Paralelamente a isso, incorpora-se a declaração do compositor francês, que considera Dó maior a tonalidade que mais tem o sentido de eternidade (DEBUSSY, 1989, p.190).

Na sequência (ainda no compasso [50]), a harpa cita o Arabesque no 1 (1891) (originalmente para piano), um arpejo dentro de Mi maior. Esse arpejo liga-se (compasso [51]) a outro acorde (o conjunto 6-z37, segundo a lista de Allen Forte) - Dó sustenido, Fá, Fá sustenido, Sol, Sol sustenido e Lá -, que é o complemento do hexacorde DEBUSSy (6-z4), ou seja, contém as classes de alturas que faltam a este para completar o total cromático. Esse acorde 6-z37, já mais dissonante, opõe-se ao Dó maior, opõe-se à "Eternidade". De fato, o que se segue a esse encadeamento é na realidade um "cortejo e funeral". A orquestra se cala por um instante, restando apenas o tantã, que faz a ligação com a seção seguinte. 


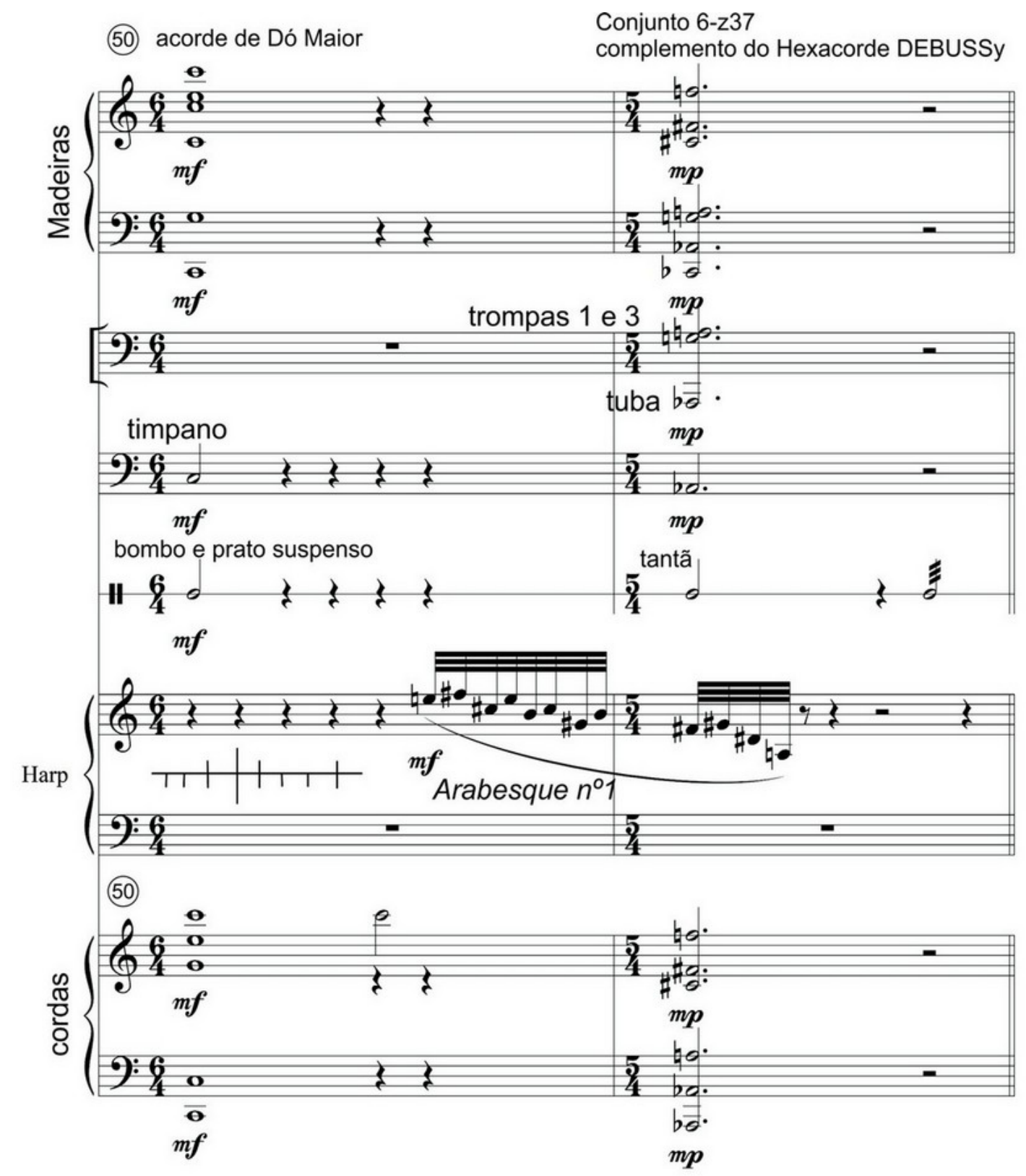

O verso ... Cortejo e funeral de um fauno é conduzido pela marimba e se inicia com o hexacorde DEBUSSy. A marimba é um instrumento que não foi explorado por Debussy, mas figura como protagonista dentro desta seção, cujo subtítulo alude a uma das peças mais emblemáticas do compositor, o Prélude à l'après-midi d'un faune. A orquestração tem papel fundamental na articulação por trazer peculiaridades para a seção. Além da marimba, que é utilizada unicamente nesta seção, sobressaem os instrumentos que produzem sons de comportamento espectral semelhante, isto é, instrumentos que possuem um ataque presente e decaimento relativamente veloz. Aos poucos desencadeia uma nuvem de notas entre marimba, vibrafone, harpa, piano e pizzicato nas cordas, lembrando, ao longe, algum momento de Éclat (1965), de Boulez. 
C (... Cortejo e funeral de um fauno)

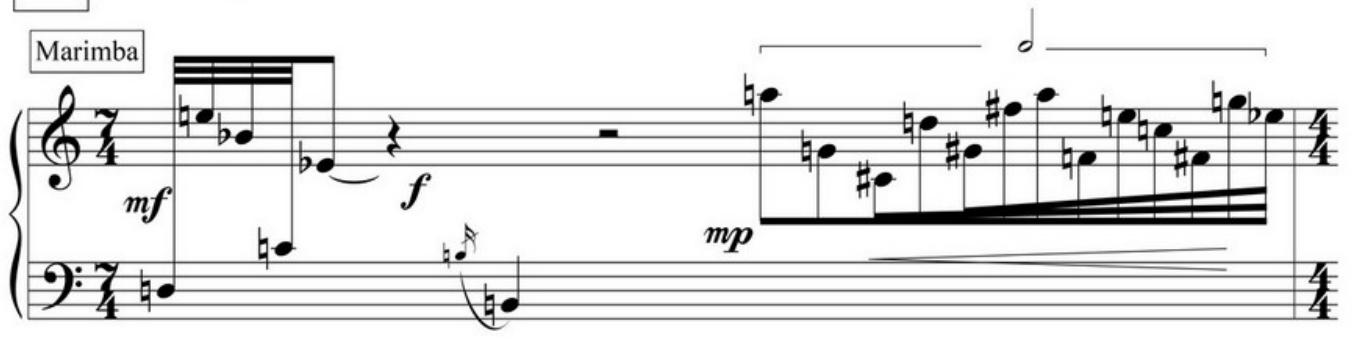

O fim desta seção - compasso [66] - ocorre na metade da peça, quase com precisão extrema: dos quinhentos e oitenta e sete (587) tempos de semínima, duzentos e noventa e quatro (294) estão antes do final desta seção, e duzentos e noventa e três (293) após (Fig. 6). Tal cálculo não foi uma programação composicional, mas observado somente no transcorrer desta análise.

\section{Harmonias}

As combinações harmônicas da peça são também um aspecto que transparece a concepção dialógica da composição. Evidencia-se uma convivência pacífica entre consonância e dissonância, entre extratos tonais, modais, cromáticos e atonais, não somente pela justaposição de acordes tonais e atonais - como o Dó maior seguido do hexacorde 6-z37 comentado acima -, mas ainda mais por sobreposições de fragmentos de sistemas distintos (tonais, modais, atonais). Parte dessas sobreposições deve-se ao processo do dialogismo mostrado empregado nas citações e alusões; outra parte, não necessariamente com um propósito referencial de alguma obra alheia, deixa transparecer naturalmente a interação entre harmonias/melodias de sistemas, a princípio, discrepantes.

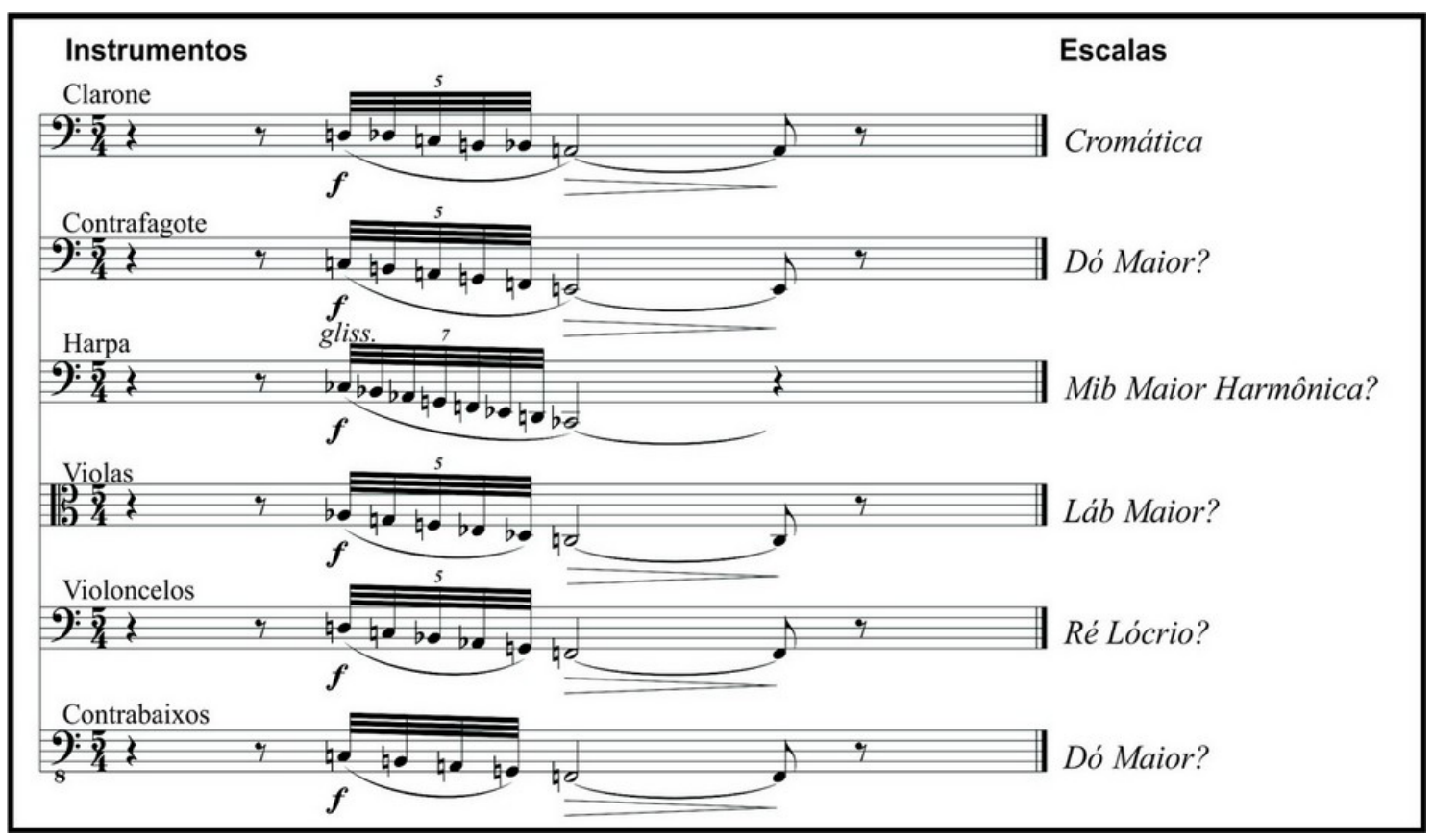


O excerto transcrito acima, que corresponde ao compasso [37], apresenta uma superposição de escalas que, em si, podem ser reconhecíveis dentro de um sistema: da perspectiva horizontal de cada extrato, observa-se movimentos tonais, modais, cromáticos. Porém, na resultante sonora não prevalece nenhuma dessas escalas e dificilmente elas podem ser percebidas separadamente. Todo o gesto, do ponto de vista vertical e pela referência auditiva, pode ser compreendido atonalmente, ou seja, os movimentos melódicos se fundem sem privilégios de alturas ou de escalas reconhecíveis. A aglomeração na região grave e a velocidade dos gestos são fatores que contribuem para essa fusão.

No compasso [48] há uma citação de Fêtes. Nessa segunda peça dos Nocturnes, de Debussy, há um movimento melódico temático que se inicia com uma escala ascendente e que é seguido de uma progressão descendente. No plano horizontal, o compositor francês apresenta esse movimento melódico em algumas escalas diferentes. A primeira aparição acontece no terceiro compasso em modo de Fá dórico, ao longo da peça surgem também versões em Lá bemol menor melódico, Lá mixolídio e na escala hexatônica. Esse procedimento foi influenciador na escolha da harmonia empregada em Cada ano sem Debussy, não mais em disposições estendidas no tempo, mas na ideia das combinações superpostas.

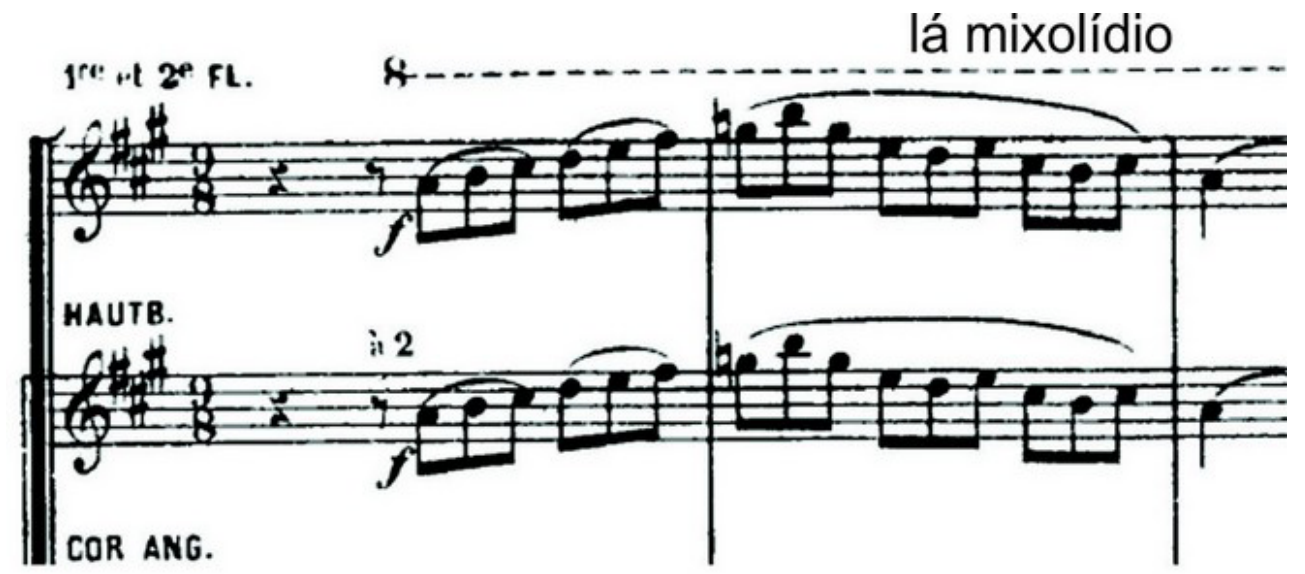

O trecho representado pela Fig. 11 a seguir apresenta o tema de Fêtes utilizado dentro da escala hexatônica e encontra-se sobre um fundo de cordas que mescla algumas escalas diatônicas, evidenciando esse caráter harmônico híbrido. 


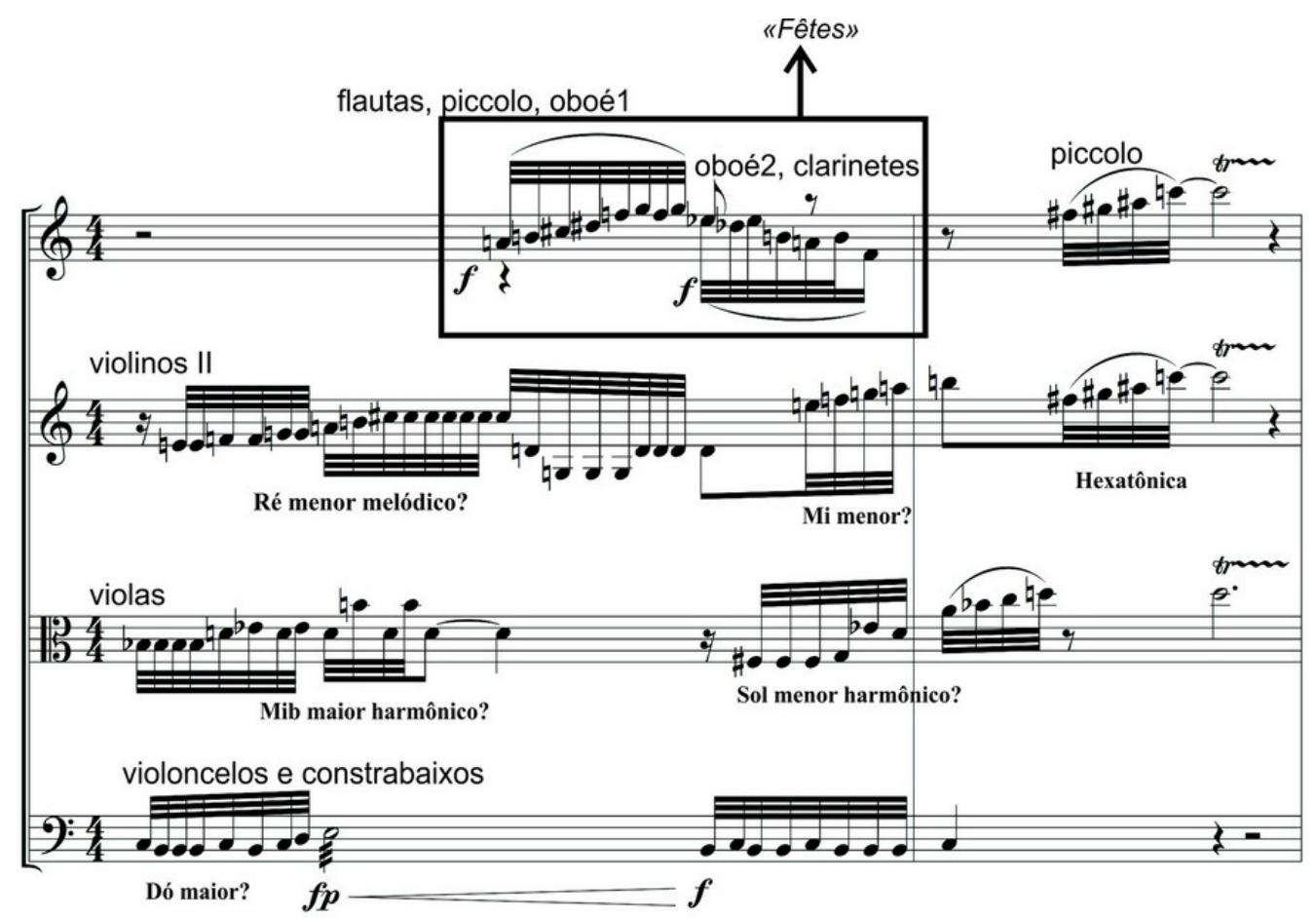

Outra apropriação desde os Nocturnes acontece nos compassos [65] e [66]. Desta vez, o material emprestado pertence originalmente à primeira peça, Nuages. Este trecho representa as misturas mais heterogêneas que acontecem em Cada ano sem Debussy, isto é, os materiais diferentes se mantêm reconhecíveis. Desta feita, a orquestração contribui para a separação dos elementos envolvidos.

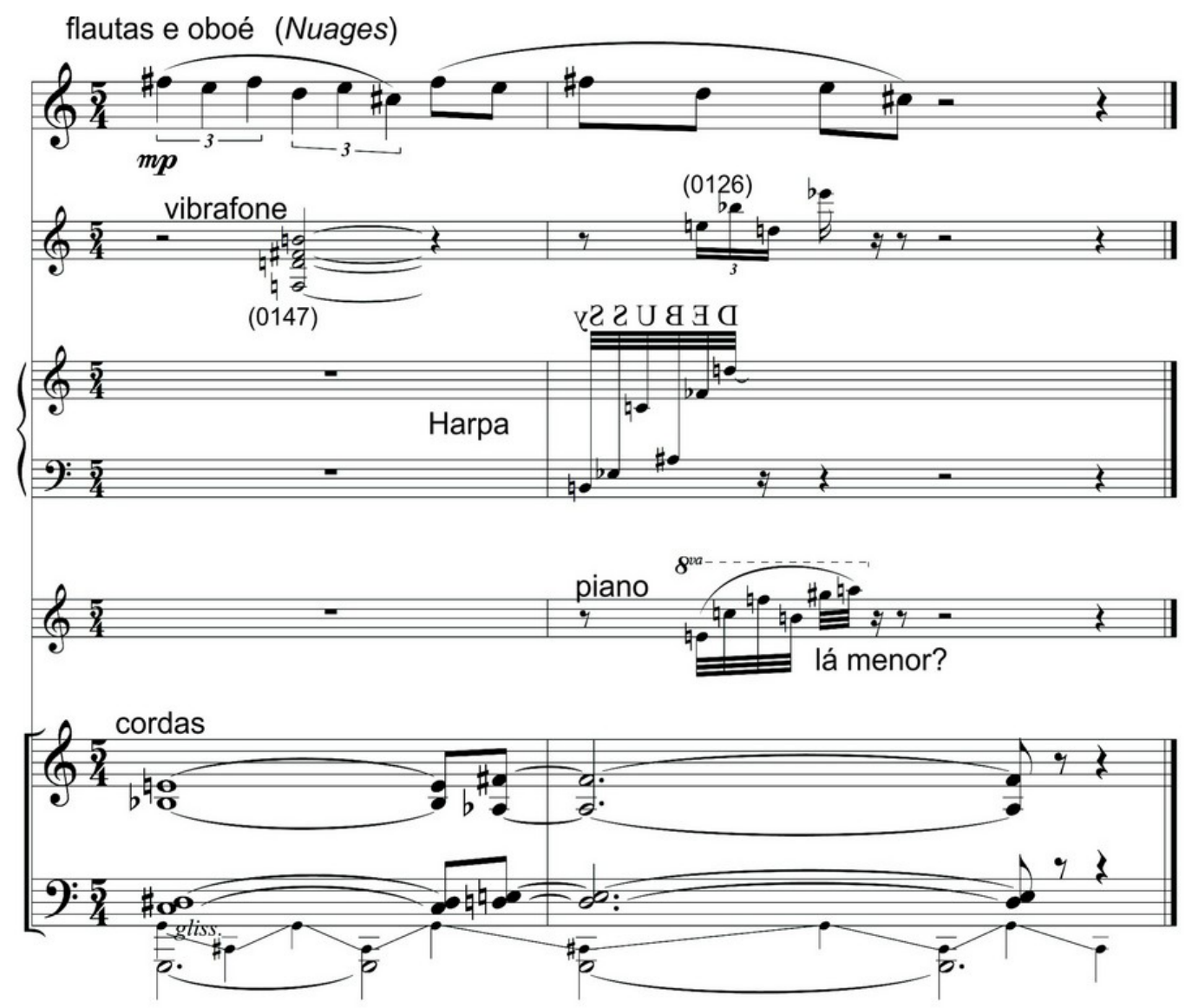


O material emprestado - que se encontra originalmente nos primeiros compassos de Nuages, orquestrado por clarinete 1 e fagote 1 em oitava - é ligeiramente modificado com um acelerando rítmico. Em segundo plano, segundos violinos e violas em tremulo fazem dois acordes que não têm classificação tonal-modal, opondo-se harmonicamente à melodia extraída de Nuages. Transpassando esses dois extratos, vibrafone, harpa e piano também apresentam materiais distintos harmonicamente. No vibrafone, dois acordes: o primeiro, em bloco, Fá, Ré, Fá sustenido e Si - o conjunto (0147); o segundo, arpejado, Mi, Si bemol, Ré e Mi bemol - o conjunto (0126). Na harpa, o Hexacorde DEBUSSy tem suas notas/letras empregadas em ordem retrógrada. No piano, uma sequência de notas que, em um contexto propício, estariam na tonalidade de Lá menor. Os primeiros violinos empregam uma técnica mais recente que consiste em pizzicato de mão esquerda seguido por glissando com arcada jogada (jété). Os violoncelos oscilam por duas notas em glissando, enquanto os contrabaixos mantêm um pedal. Além da natureza diferente dos materiais empregados em todo o trecho e da orquestração, a possível reconhecibilidade da voz alheia através do dialogismo mostrado (Nuages, nas flautas e oboé) favorece a distinção dos planos.

Esse tipo de procedimento é previsto por Cope (1997, p.230-238) - em Techniques of the contemporary composer - e se enquadra em um caso de descategorização (decategorization) que engloba a mesclagem de técnicas composicionais (citação, atonalismo, novas técnicas instrumentais etc.).

\section{Dialogismos mostrados e o comentário musical}

Voltando às ideias de Berio a respeito da sua Sinfonia, isto é, ao poder de comentário que a utilização do material de outrem pode evocar (BERIO, 1988, p.95), o dialogismo mostrado em Cada ano sem Debussy traz enunciados musicais que criam interlocuções com a poética de seu homenageado e com obras de outros compositores ligados, de alguma forma, à estética suscitada pelo compositor francês. A obra debussista e o tecido dialógico que se formou em torno dela são os objetos comentados e, através de citações e alusões, ocupam um papel de destaque na peça analisada aqui. Maurício De Bonis (2010, p.34), com base nos escritos da musicóloga Zofia Lissa, expõe que a citação estabelece uma relação metonímica com a obra citada.

Neste momento, a partir dos comentários musicais, vamos desdobrar algumas reflexões sobre os diálogos envolvidos no processo composicional. Exporemos exemplos de apropriação do enunciado de Debussy e de alusões a um conjunto de recursos expressivos adotados pelo compositor. As citações seguem as observações de De Bonis (2010, p.34) de que não devem ser muito longas, de modo a não perturbar o transcorrer do discurso, nem muito curtas a ponto de não serem perceptíveis. Vamos demonstrar também algumas utilizações do hexacorde DEBUSSy, que, juntamente aos empréstimos musicais de materiais alheios, são os elementos de tributo unificadores da forma.

O primeiro verso, intitulado ... Sob as cãs de linho, revela prontamente duas versões do hexacorde DEBUSSy. Primeiramente nos violoncelos mais agudos, compasso [4]: 


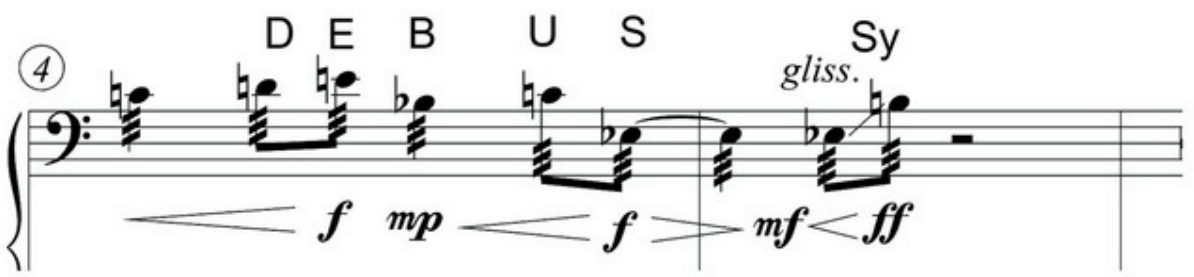

Depois em um gesto orquestrado por piccolo e piano, no compasso [7]:

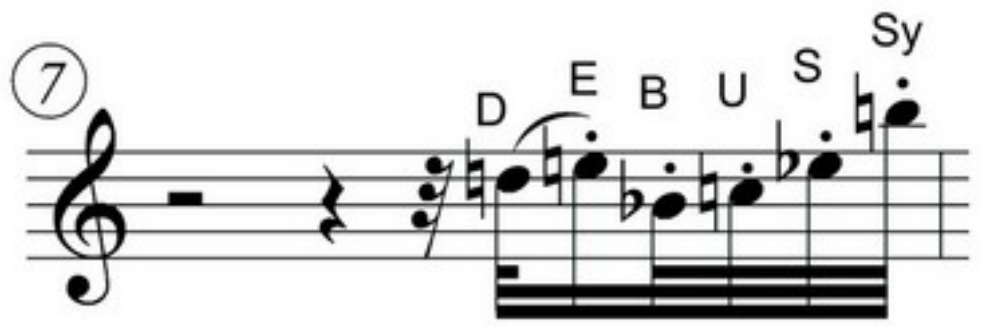

Como exemplo de diálogo com a obra de Debussy, destacamos a escrita dos instrumentos de madeira dos compassos [10] e [11]. Chun-Hsien Chang (2002) expõe que, em suas orquestrações, Debussy dá mais proeminência para as madeiras da orquestra, o que o diferencia de seus contemporâneos da escola germânica. Desta forma, ele segue mais a tradição de compositores do barroco francês, como Jean-Baptiste Lully e Jean-Philippe Rameau, que também favoreciam essa família de instrumentos (CHANG, 2002, p.29).

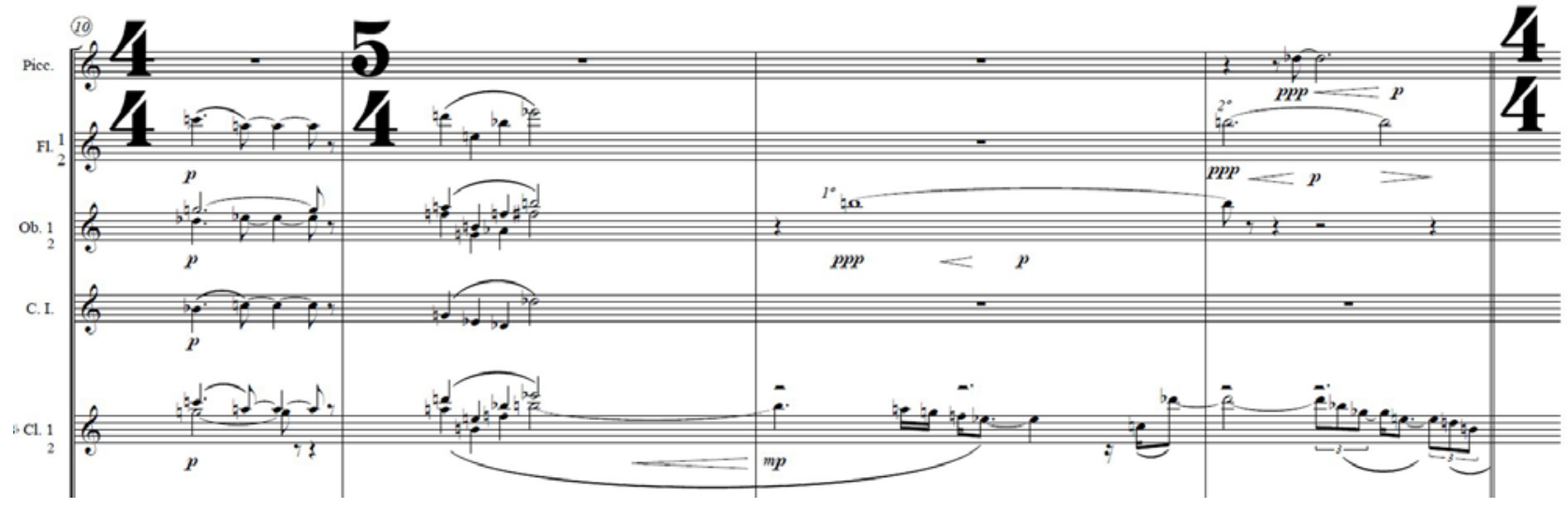

O encadeamento em movimentos paralelos (compasso [11]), também presente em outros momentos da peça, memora o estilo debussista. Não é uma citação direta, mas uma alusão a uma característica marcante nas obras do compositor. Esse tipo de condução de vozes é uma atitude - e, de acordo com Bakhtin (2016, p.78), a "atitude humana é um texto em potencial", portanto, enunciado - pela qual Debussy se posiciona mais próximo de obras pré-renascentistas e do organum paralelo do que dos compositores românticos e das concepções acadêmico-musicais oitocentistas.

Esses dois aspectos da poética debussista - a orquestração que privilegia as madeiras e o paralelismo harmônico - são muito bem exemplificados no oratório Le martyre de Saint Sébastien (1911). O início desta obra é fundamentado nessas características. 
Gabriele d'Annunzio

$1^{\circ}$ Acte -- La Cour des Lys

Claude Debussy

Prélude

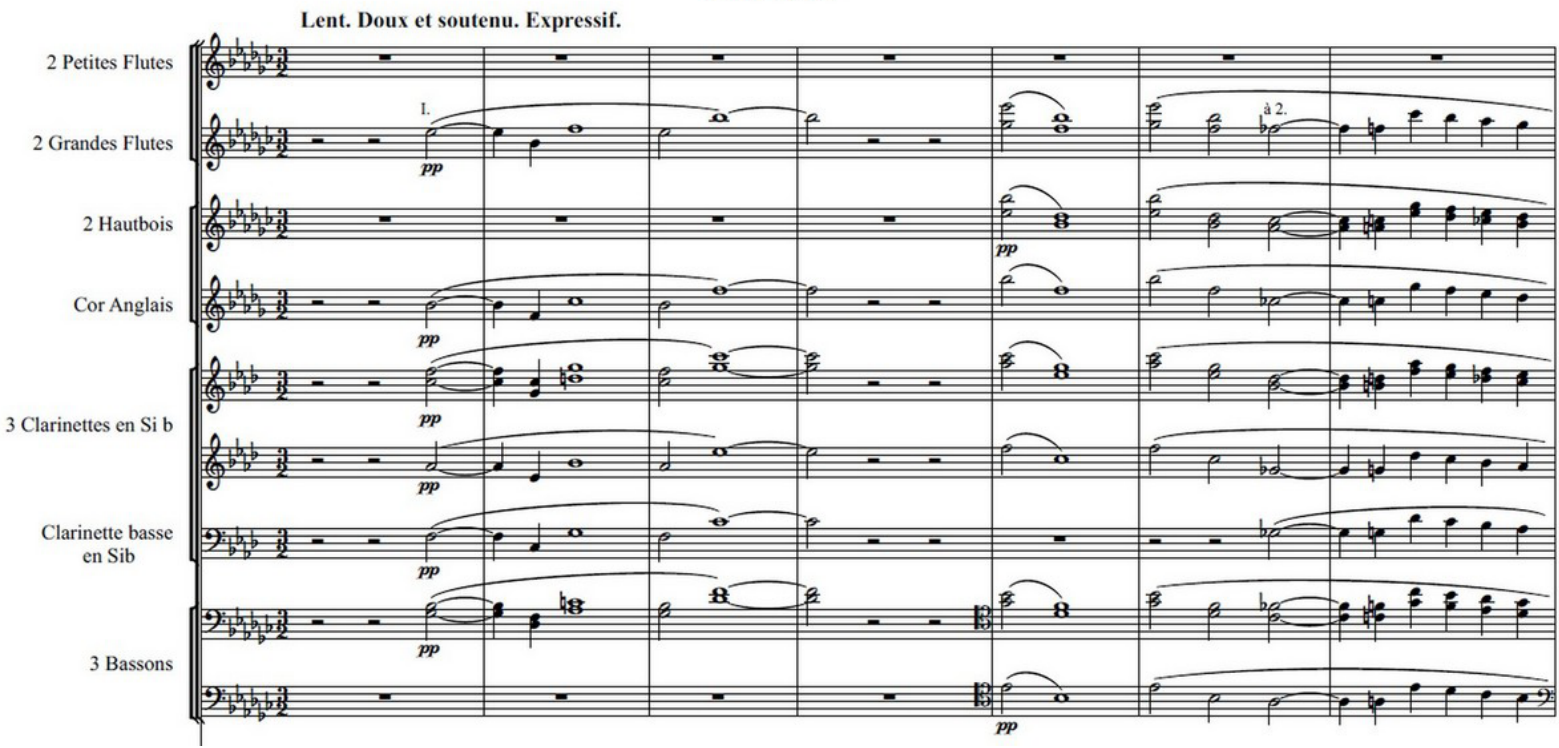

Retornando à Fig. 15, observa-se um destaque do clarinete 2. Primeiramente, ele surge em evidência a partir de um processo de "filtragem" da harmonia do compasso [11], prolonga a nota Si e se desfaz em uma sequência (Si, Lá, Sol, Fá, Mi bemol) dentro da escala hexatônica por tons - escala comumente atribuída a Debussy como o seu primeiro explorador sistemático. São as mesmas notas do final de Syrinx (1913), para flauta solo.

O subtítulo dessa seção remete ao prelúdio La fille aux cheveux de lin (1910). Há uma sutil menção a essa peça. A sequência melódica do clarinete 2 , a começar pelo Ré bemol agudo, utiliza o prelúdio de Debussy, que é transformado logo em seguida para dar início ao verso seguinte.

Em seus primeiros compassos, a seção ... Antes dos oceanos apresenta segundos violinos em arpejos rápido - o movimento de arpejo de cordas pode ser encontrado em La Mer (1905) - e glissando no vibrafone, piano e harpa - glissandi e arpejos de harpa na obra de Debussy foram associados por Chang (2002, p.215) a uma delicada atmosfera que pode sugerir águas fluindo. Embora a composição não tenha sido pensada pelo viés impressionista, a associação semântica se faz pertinente no contexto deste verso, uma vez que invoca a imagem do oceano e conduz para uma citação de La Mer nos compassos [15-16].
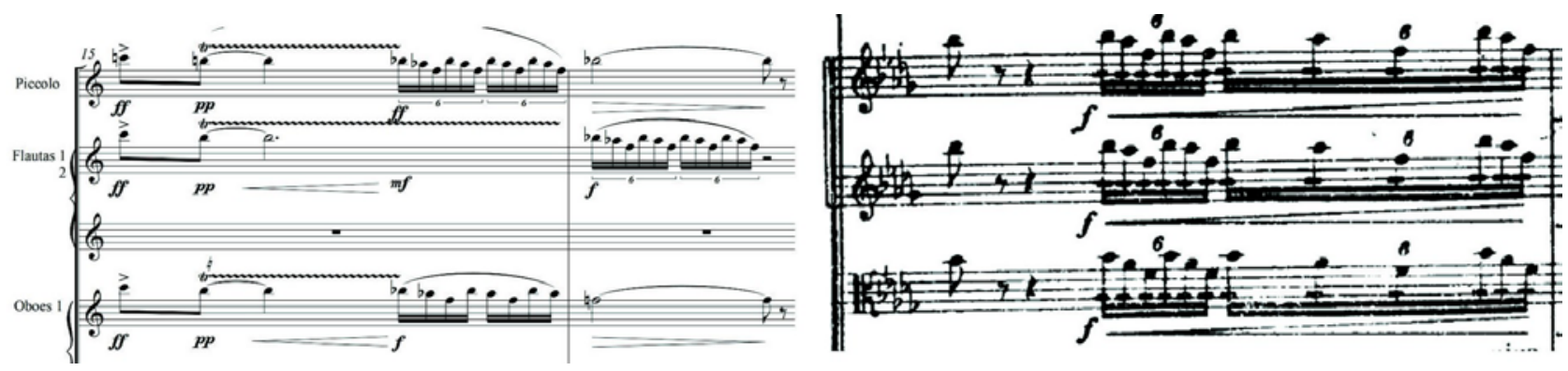
A citação de La Mer logo se esvai. Justapõe-se mais uma forma melódica do hexacorde DEBUSSy em um perfil melódico descendente, como uma onda se desfazendo.

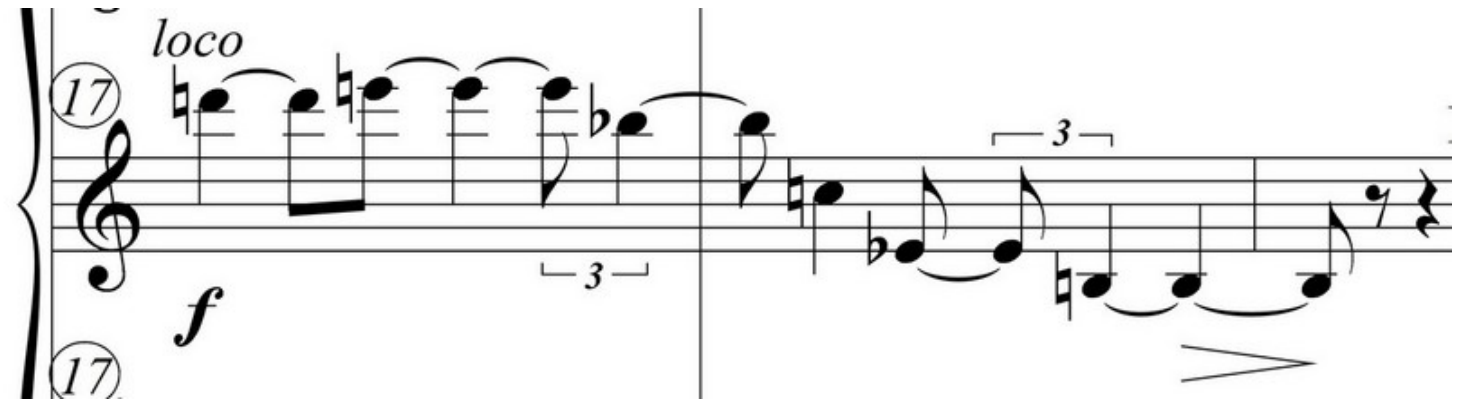

A essa forma melódica do hexacorde, seguem duas disposições harmônicas, nos compassos [19] e [21], com mudanças sutis na orquestração e na disposição das notas entre elas. No meio dessas duas aparições (no compasso [20]) é utilizado o hexacorde sobre o nome de Sacher. As notas dos dois hexacordes são semelhantes, com uma única variação: onde em um (SACHER) há Lá, no outro (DEBUSSy) há Si bemol.

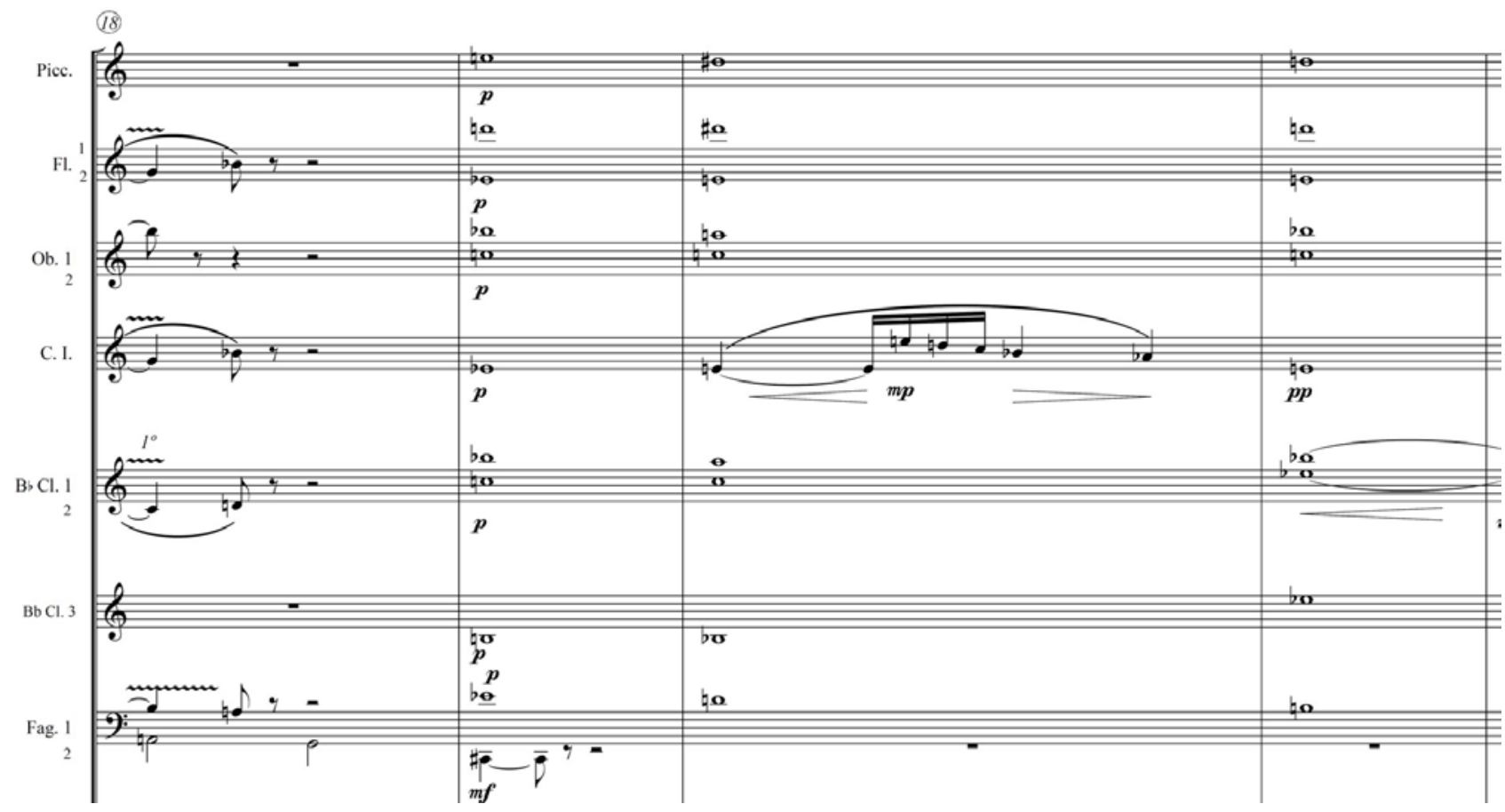

O corne inglês que sobressai no compasso [20] realiza mais um movimento melódico dentro da escala hexatônica. $O$ instrumento retoma o protagonismo no compasso [30] através do dialogismo mostrado. Ali, faz-se menção a outra passagem de Nuages que também se destina ao corne inglês. $O$ enunciado apropriado sofre algumas alterações no ritmo. 
Cada ano sem Debussy

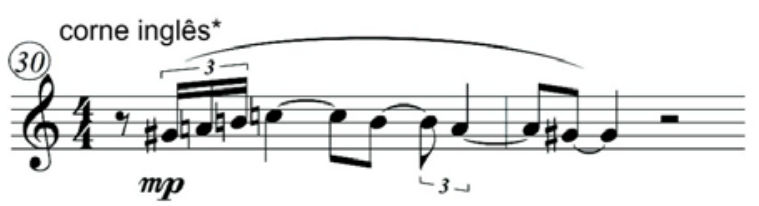

Nuages

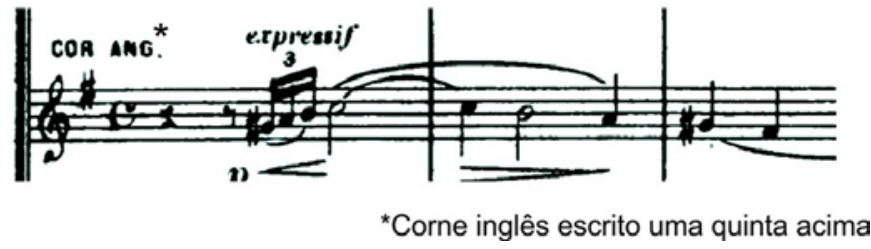

Em ... Brumas das noites eternas, a terceira seção da peça, também há uma apropriação dos Nocturnes. Nessa ocasião, há uma substituição da instrumentação: o enunciado originalmente apresentado nos trompetes em Fêtes é legado (com modificações) para a trompa.

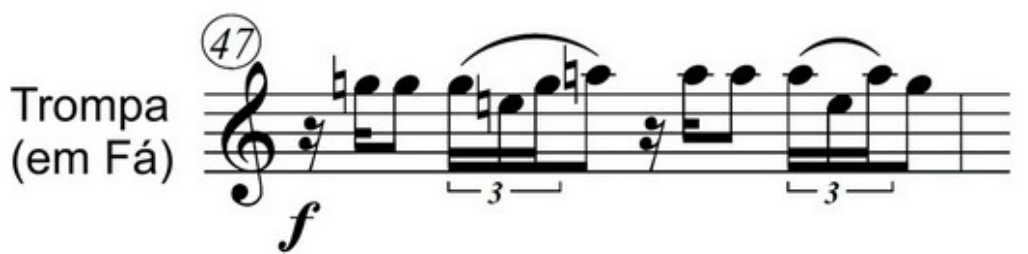

Outro exemplo encontra-se na seção denominada ... Grinaldas (compassos [104113]). Nesse trecho, há proeminência de flauta, violas e harpa, o que rapidamente alude à Sonata para flauta, viola e harpa (1915), de Debussy. O enunciado inicial da Sonata, na parte da harpa, é ligeiramente modificado.
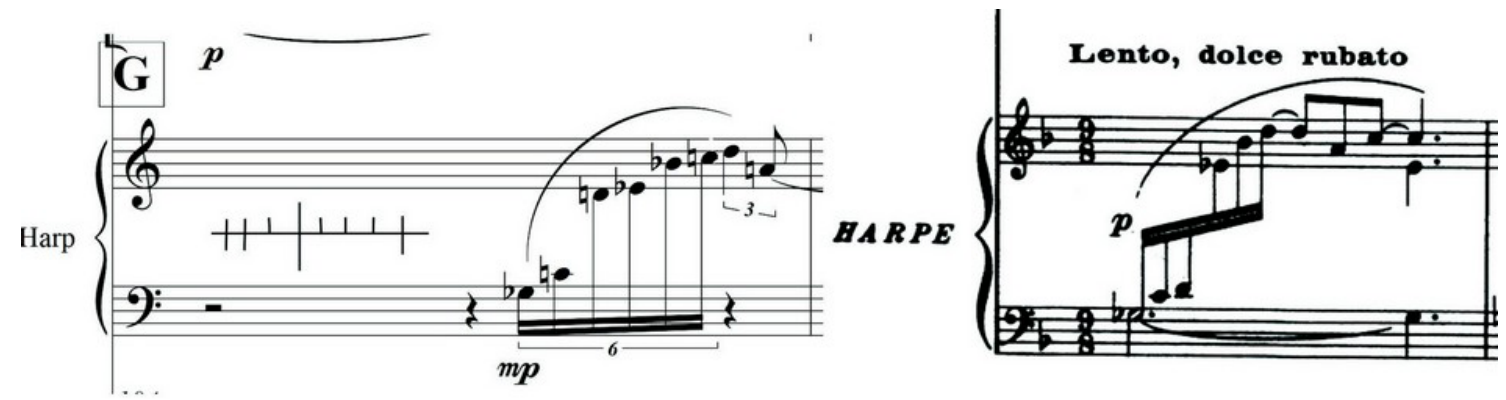

No último compasso desta seção [113], o hexacorde DEBUSSy é utilizado em movimento ascendente com dobramento de quartas/quintas e oitavas paralelas que se assemelha à La cathédrale egloutie (1910). Coincidentemente, as duas primeiras notas do prelúdio são as mesmas do hexacorde sobre o nome do compositor. Aproximando-se de La cathédral, em Cada ano sem Debussy há igualmente um ataque precedente sobre a nota Sol na região grave (Sol-Ré no prelúdio debussista, mas Sol-Dó em Cada ano sem Debussy). Com isso, observa-se que o enunciado de Debussy não está identicamente replicado, mas é perceptível como discurso reportado. 

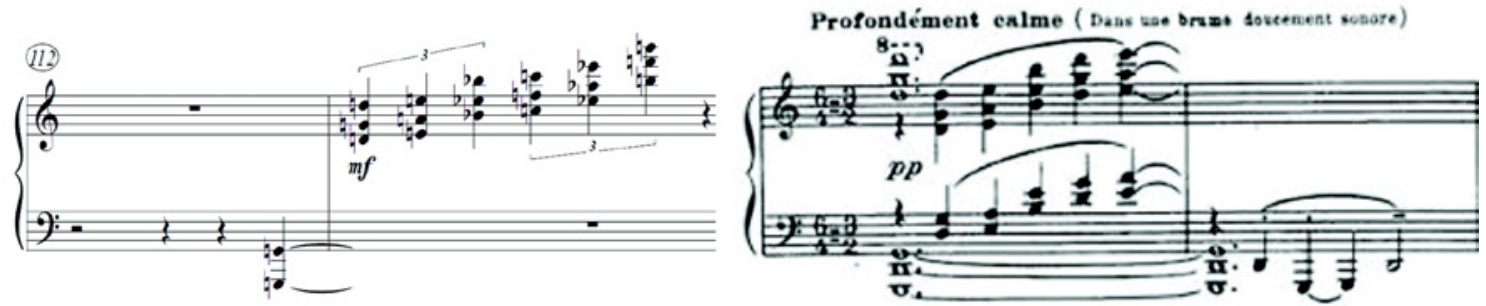

O que emerge na sequência - no verso ... Herança das florestas - não é uma catedral, mas a floresta ${ }^{4}$ de Pelléas et Mélisande (1902). Os baixos do segundo compasso de La cahédrale engloutie (Ré, Sol, Ré) são substituídos por Ré, Lá, Sol, Lá... melodia grave marcante no início da ópera de Debussy.
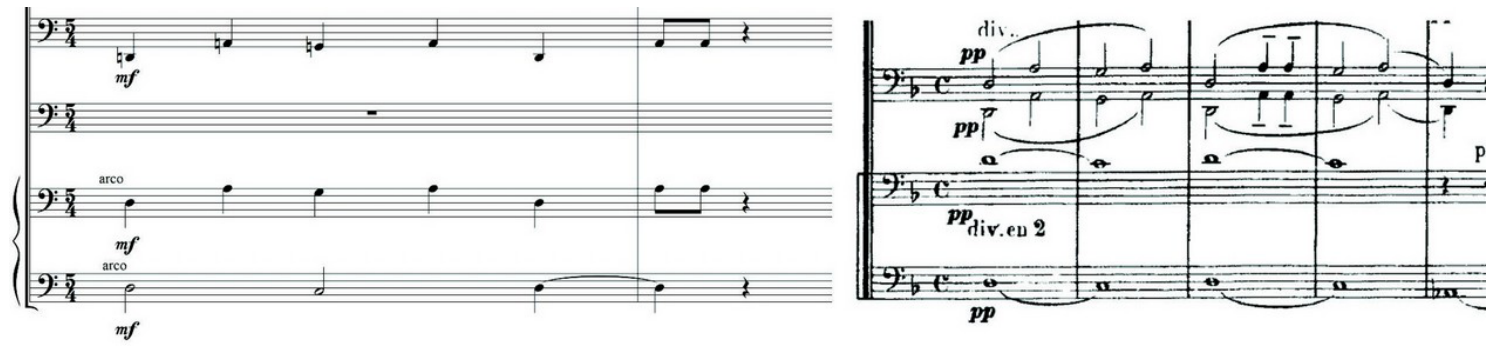

Tanto Messiaen como Dutilleux foram presenteados ainda crianças com a partitura de Pelléas et Mélisande. Ambos relatam a importância que essa obra teve para os seus desenvolvimentos musicais (MESSIAEN, 1944, p.4; DUTILLEUX, 1997, p.28). Boulez (1986, p.317) vai um pouco mais longe: para ele, a ópera de Debussy pertence à classe de obras que servem como uma espécie de espelho no qual uma cultura inteira pode se ver transfigurada. Nesse ponto, podemos salientar a relevância que Debussy teve para o futuro da música e seu enredamento dialógico com as gerações subsequentes de compositores.

\section{Diálogo entre sujeitos e mais dialogismos mostrados}

Boucourechliev (1993, p.123) diz que Debussy escapa a qualquer filiação. No entanto, buscando traçar o que para nós representa o dialogismo entre sujeitos, o autor apresenta uma cadeia de respostas até e a partir do compositor francês. Ele identifica que os antecessores de Debussy não são Hector Berlioz nem César Franck, mas Guillaume de Machaut, Claude Monteverdi e Franz Liszt, e os seus descendentes não são os "debussistas" nem Ravel, mas Messiaen e Boulez. As propostas do Círculo de Bakhtin revelam o homem como um ser imanentemente dialógico: "[...] seu mundo interior é formado de diferentes vozes em relação de concordância ou discordância" (FIORIN, 2016, p.61). Esse dialogismo entre sujeitos é o que evidencia, antes de mais nada, a dimensão social de um enunciado.

Debussy toma uma postura em relação às obras anteriores ("discorda" ou "concorda") e, embora ele tenha declarado em 1910 que não tinha discípulos (DEBUSSY, 1989,

4 A primeira cena do primeiro ato de Pelléas et Mélisande acontece em uma floresta (une forêt). 
p.268), isso não significa que, em anos posteriores, muitos compositores não tenham buscado diálogo com sua obra. É inegável sua influência sobre a geração do início do século XX, principalmente entre seus compatriotas, dentre os quais podemos ressaltar Messiaen, Dutilleux, Edgard Varèse e Boulez.

Em Cada ano sem Debussy, esses compositores são colocados em diálogo. Um exemplo disso pode ser observado no compasso [22]. O clarinete 1 irrompe em destaque com uma figura muito próxima à do clarinete solo em um momento de Métaboles (1964), de Dutilleux. Na sequência, a melodia se transforma em trechos transpostos da Première rhapsodie, para orquestra e clarinete solista (1910). Para fechar o momento solista do clarinete, os primeiros violinos tocam o início de Turangalîla (1948), de Messiaen:

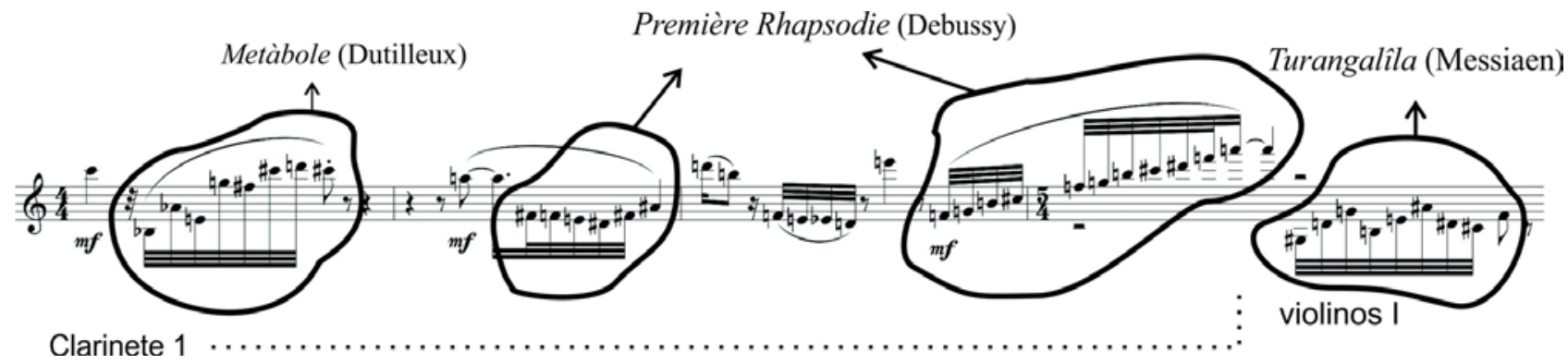

A voz de Messiaen é invocada novamente nos compassos [43-45]. Não se trata de uma citação ipsis litteris. O enunciado do compositor é apropriado e retrabalhado, mas de uma maneira que seja reconhecível e assimilável para o ouvinte familiarizado, isto é, que, apesar das modificações, soe como um discurso reportado. Muitos autores, como Didier Guigue (2011, p.30), colocam Messiaen como sucessor do aporte debussista. No material emprestado, percebe-se a rítmica semelhante e o conteúdo intervalar apoiado na escala hexatônica que Messiaen incorporou em seus modos de transposições limitadas.
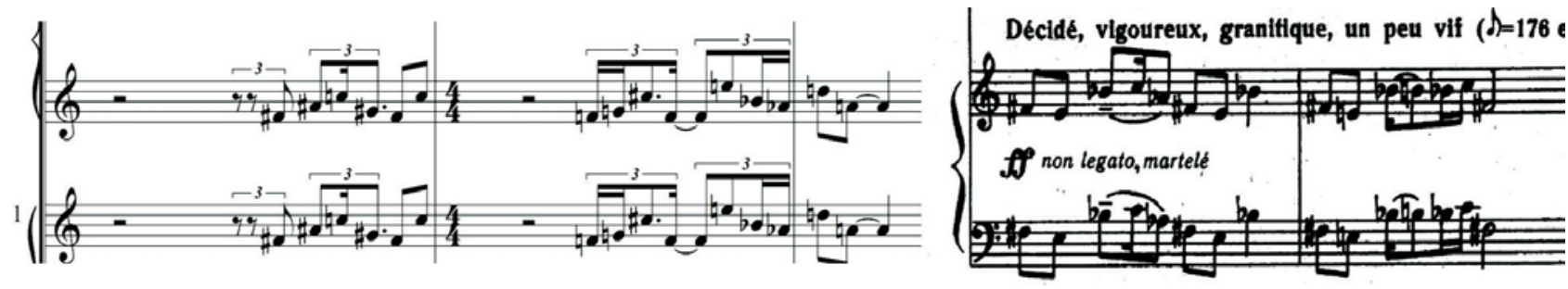

Já ... Esfinge de níquel não tem uma relação direta com algum título de Debussy, mas coloca um símbolo do passado (esfinge) com algo um pouco mais recente (manipulação do níquel). Neste verso, aproxima-se Density 21.5 (1936), de Varèse, a Syrinx, de Debussy, ambas para flauta solo. São peças emblemáticas do repertório para o instrumento. Density parece possuir algumas raízes constitutivas em Syrinx. As figuras iniciais das duas obras apresentam uma semelhança evidente: o mesmo conteúdo intervalar, com um ritmo retrógrado entre elas. 


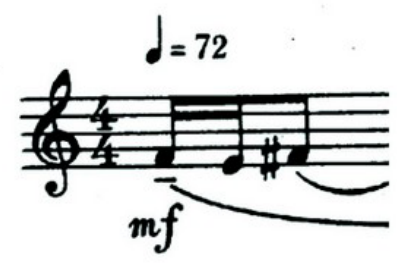

Très modéré

Density 21.5 foi composta a pedido do flautista Georges Barrère para sua primeira flauta de platina (a densidade da platina é próxima de $21,5 \mathrm{~g} / \mathrm{cm}^{3}$ ). Hoje, o banho de níquel é bastante comum nas flautas comerciais de baixo custo.

Varèse tinha grande admiração por Debussy, tanto pelo homem como pelo músico. Ele conta com orgulho que foi protegido e ajudado pelo compositor de Syrinx (VARĖSE, 1985, p.156). Nos compassos [86-88] de Cada ano sem Debussy, as peças dos dois compositores se complementam. A flauta em proeminência demarca o enunciado de Varèse, que é seguido pelo enunciado de Debussy:

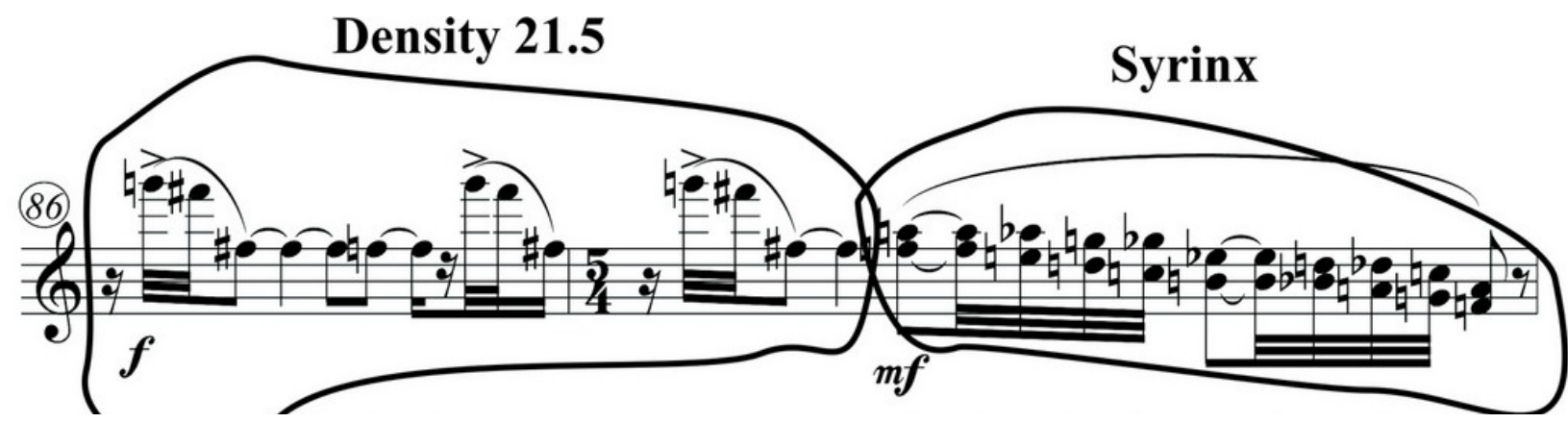

Processo similar acontece nos compassos [106-108]. Desta vez, o diálogo acontece entre L'artisanat (do Le martaeu sans maître, 1954), transposto (o original é para flauta em Sol) de Boulez, e Garak (1963), de Isang Yun.

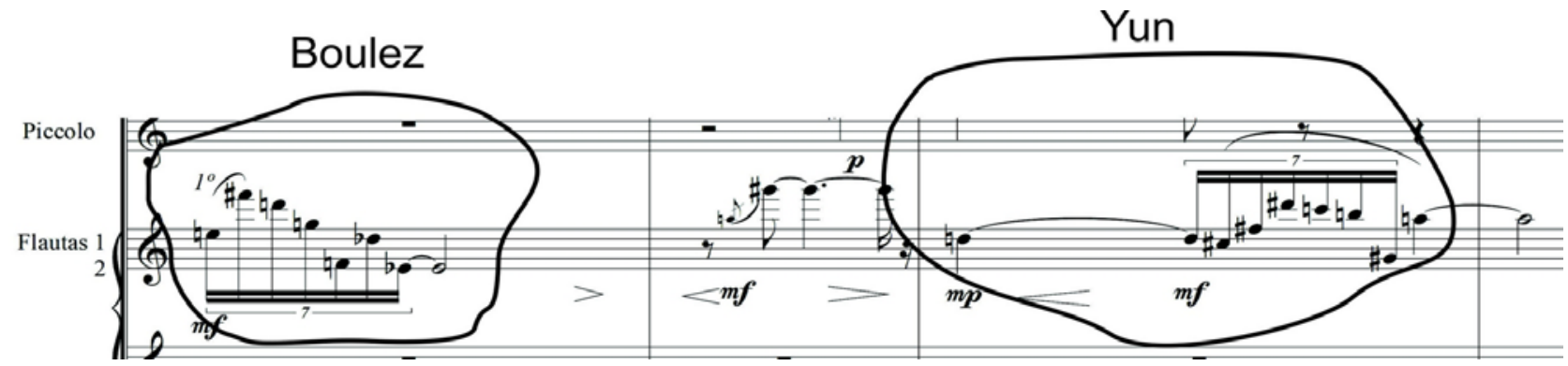

Em ... Festejo dos ancestrais, o hexacorde DEBUSSy aparece nos violinos 1, imediatamente após o tetracorde BACH (compassos [97-98]). No contexto de ancestralidade, podemos recordar da fala de Debussy, que aclamou Bach como "o pai de todos nós" (DEBUSSY, 1989, p.92). 


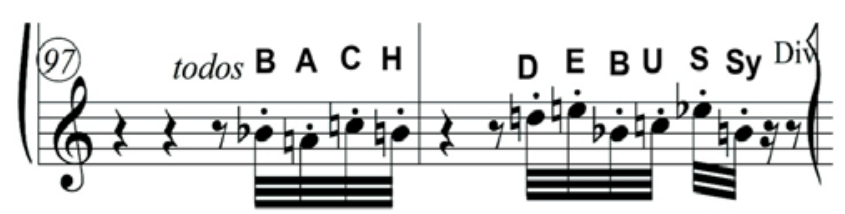

Corroborando o caráter festivo, os segundos violinistas seguram seus instrumentos "como a um bandolim" e são acompanhados pelo pandeiro em uma rítmica quase popular. O artifício de simular um instrumento - seja bandolim, cavaquinho, banjo... - e seu comportamento típico na esfera da música popular com o violino pode também ser observado em dois compositores que têm conexões atestadas com Debussy e sua obra: Villa-Lobos, em seu Choros $n^{\circ} 7$ (Settimino) (1924), e Ravel no segundo movimento, Blues, de sua Sonata para violino e piano no 2 (1927). Debussy mesmo já propôs evocar a sonoridade do bandolim e o caráter popular em sua peça Mandoline (1882) para voz e piano sobre um texto de Paul Verlaine.

\section{(... festejo dos ancestrais)}

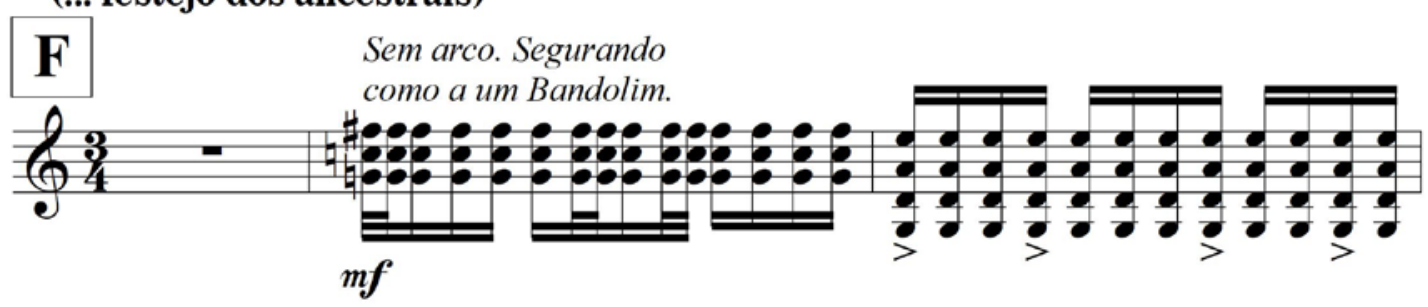

Para Boucourechliev (1993, p.124), a agressividade com que, seguidamente, Debussy rejeitou Richard Wagner mostra o ascendente exercido nele. Em Cada ano sem Debussy, os violoncelos, no compasso [116], apresentam o motivo inicial do Prelúdio de Tristão e Isolda (1859), de Wagner, este que ficou conhecido como o "Motivo do desejo". O famigerado "acorde Tristão", como normalmente se denomina o primeiro acorde do Prelúdio, aparece deslocado em relação ao motivo referido em seu contexto original. No compasso [119], o piano intervém solitariamente, com uma figuração de caráter oposto ao drama que se estabelecia. O drama é retomado, mas uma segunda intervenção do piano, agora dobrado com o clarinete 1, irrompe com uma citação de Gollinwogg's Cakewalk, da suíte para piano solo Childrens's Corner (1908), de Debussy. Sob tudo isso, ou seja, nos compassos [117] ao [121], tuba e contrafagote (depois contrabaixos reforçam a orquestração) realizam mais uma forma do hexacorde DEBUSSy.

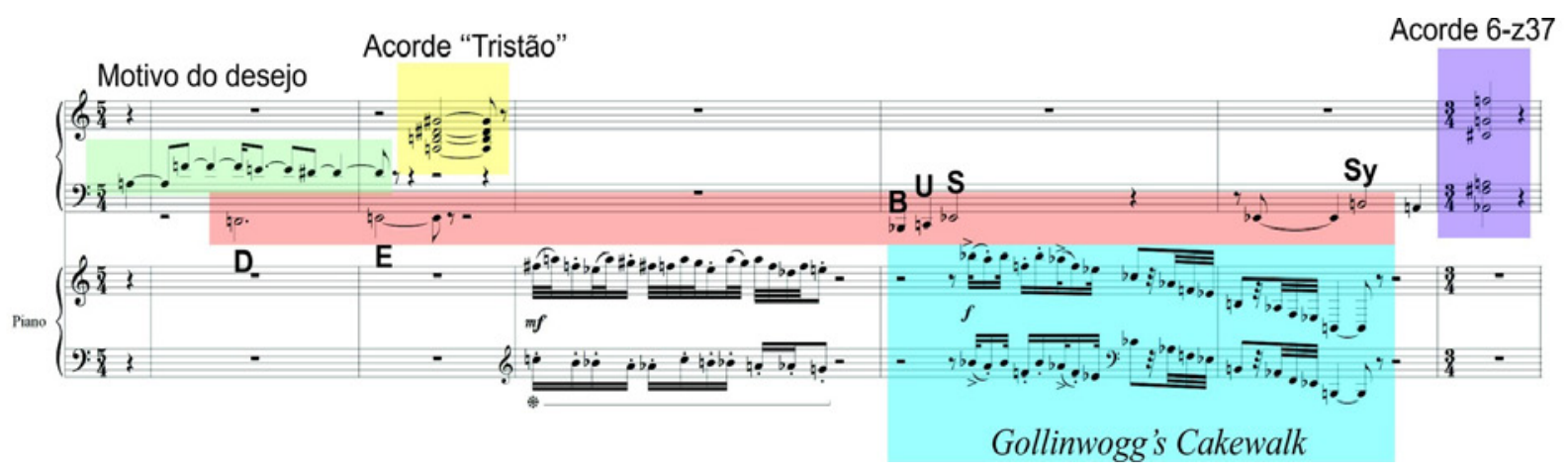


Em Gollinwogg's Cakewalk também há uma citação do "Motivo do desejo", mas Debussy a trata de forma humorística. Esse tipo de tratamento caracteriza o discurso bivocal dentro do dialogismo mostrado. A voz de Debussy se mistura à de Wagner. Não é possível distinguir onde acaba a voz de Wagner e onde começa a de Debussy, e, trazendo para este contexto, nem onde se encontra a voz própria do compositor de Cada ano sem Debussy nesse excerto.

A aproximação entre esses compositores foi uma das razões do subtítulo deste verso (... Herança das florestas), pois nos remete à opinião de Boulez (1986, p.40), ao dizer que Debussy é o "verdadeiro herdeiro de Wagner, e não os compositores que copiaram o Anel". Boulez defende a inter-relação histórica entre esses compositores. Ele declara que Debussy foi preparado e condicionado por Wagner, seu vocabulário musical é impensável sem a evolução do cromatismo wagneriano, assim como sua estética só pode ser pensada como uma reação violenta contra Wagner. Boulez identifica na postura de Debussy em relação a Wagner aquilo que para nós caracteriza um exemplo notório de dialogismo entre sujeitos.

Pouco antes da última seção (nos compassos [124] e [125]), os violoncelos realizam uma melodia sobre o hexacorde SACHER, o mote harmônico das doze peças encomendadas por Rostropovich para o seu instrumento, antecipando as "invocações" da última seção.

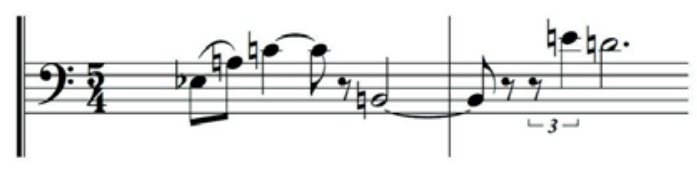

O último verso denomina-se ... Invocações. Esta seção, como última da segunda parte da obra, relaciona-se com ... Brumas das noites eternas, última seção da primeira. Ambas as seções são iniciadas com um contraponto a três vozes, com dobramentos orquestrais que demandam quase todo o efetivo instrumental e abrangem boa parte da tessitura possível da orquestra.

A peça termina com uma melodia ascendente sobre as notas do conjunto DEBUSSy, concluindo com duas badaladas nos sinos tubulares. No penúltimo compasso, sobre a ressonância do sino e do piano, fixa-se, entre os violinos e contrabaixos, um intervalo de quinta justa (Mi - Si) composta, como mais uma menção a esse intervalo típico na música medieval e a ancestralidade com a qual Debussy restabelece diálogo. Além do nome de Debussy, os nomes de Bach (compasso [128]) e Haydn (compasso [132]) também são "invocados" nessa seção. 


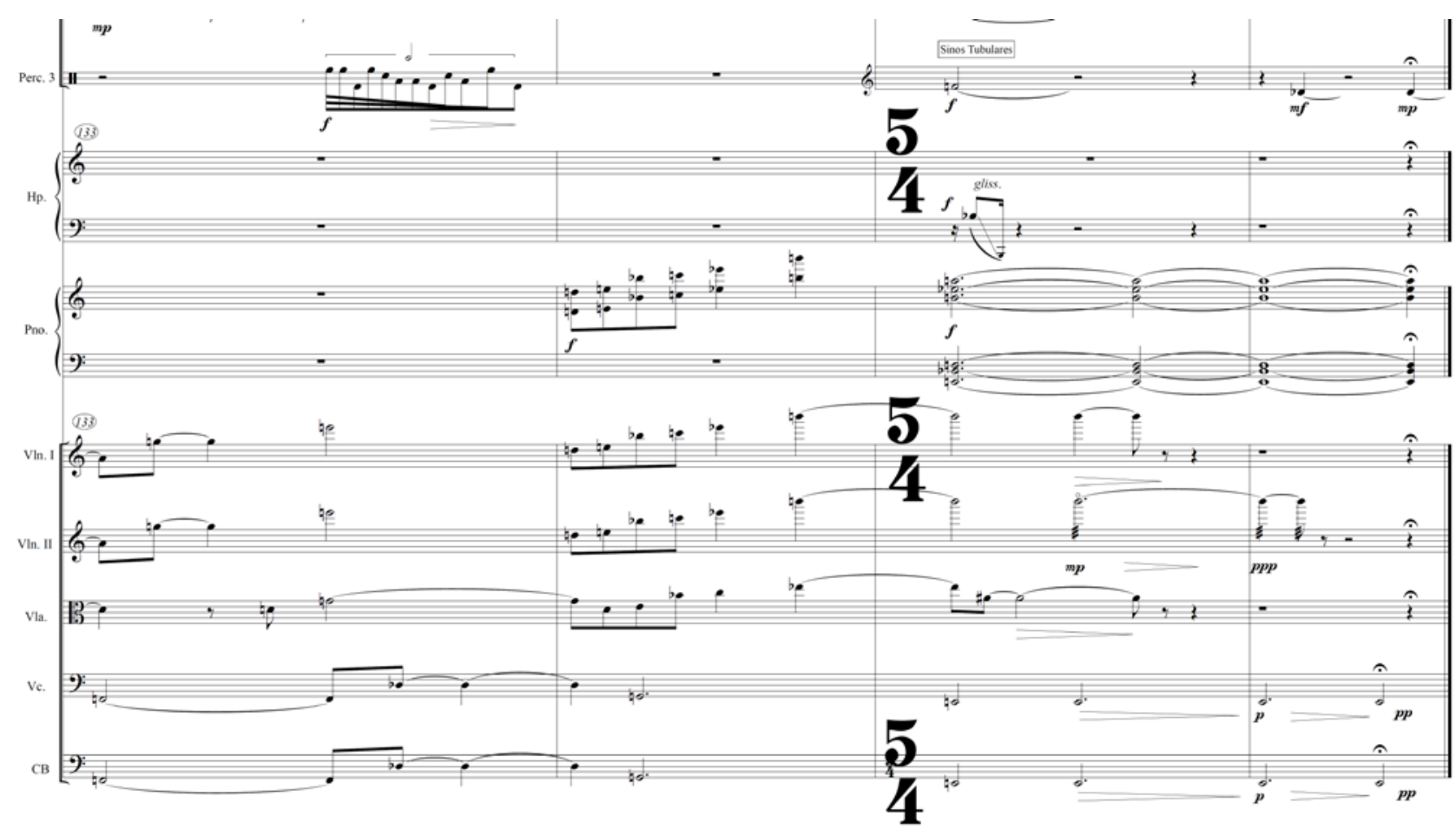

Diante dessa proliferação de enunciados alheios, referências e diálogos com um coro de vozes de outrem, Cada ano sem Debussy estabelece uma ligação com obras emblemáticas que se relacionam de modo parecido com múltiplas realizações de dialogismo mostrado, dentre as quais podemos mencionar, além da Sinfonia de Berio, Musique pour les soupers du roi Ubu (1966), de Bernd Alois Zimmermann; Votre Faust (1968), de Henri Pousseur; e Frankenstein symphony (1997), de Francis Dhomont.

\section{Conclusão}

Cada ano sem Debussy: dez versos sobre o seu nome foi estudada aqui como um tipo de comentário musical em forma de homenagem à obra de Debussy. Escolhas texturais, orquestrais, harmônicas e melódicas revelam um dialogismo com a obra debussista e com aqueles que também dialogaram com ela.

Os estudos e reflexões de Bakhtin sobre enunciado e dialogismo e a apropriação desses conceitos para a música foram ferramentas eficazes e reveladoras para a investigação do processo criativo da peça analisada. Salles $(2014$, p.23) ressalta que os pensadores interessados na compreensão dos processos de criação falam sobre uma rede que se constrói e esses pensadores da criação, por sua vez, necessitam de uma abordagem que esteja também nesse paradigma relacional. Para a autora, "o modo de apreensão de um pensamento em rede só pode se dar em rede" (SALLES, 2014, p.23).

Bakhtin (2014, p.86) entende que o enunciado não pode deixar de tocar os milhares de fios dialógicos. Visto desta maneira, os enunciados musicais, atados uns aos outros por esses fios, ganham significado quando nexos são estabelecidos. Daí o interesse em retomarmos - seja na análise musical ou na própria composição - conceitos e citações que podem ser revistos em novos ambientes, gerando outras conexões. 
O pensamento composicional dialógico em Cada ano sem Debussy, descrito em parte neste artigo, traz a ideia de que o enunciado individual é participante ativo de um diálogo social (dialogismo entre sujeitos). E, nesse redemoinho de diálogos, acordamos com Berio (1988, p.6) e entendemos que a maneira mais eficaz de falar da própria obra é falando do outro.

\section{Referências}

BACH, Ana Madalena. Memórias íntimas. São Paulo: Cultura Brasileira, 1938.

BAKHTIN, Mikhail. Estética da criação verbal. 6. ed. São Paulo: WMF Martins Fontes, 2011.

BAKHTIN, Mikhail. Questões de literatura e de estética: a teoria do romance. 7. ed. São Paulo: Hucitec, 2014.

BAKHTIN, Mikhail. Os gêneros do discurso. São Paulo: Editora 34, 2016.

BARROS, Diana Luz Pessoa de. Contribuições de Bakhtin às Teorias do Texto e do Discurso. In: FARACO, Carlos Alberto; TEZZA, Cristóvão; CASTRO, Gilberto de (org.). Diálogos com Bakhtin. 4. ed. Curitiba: Ed. UFPR, 2007. p. 21-38.

BERIO, Luciano. Entrevista sobre a Música Contemporânea. [Entrevista cedida a] Rossana Dalmonte. Rio de Janeiro: Civilização Brasileira, 1988.

BERIO, Luciano. Interviste e Colloqui. Torino: Einaudi, 2017.

BOUCOURECHLIEV, André. A linguagem musical. Lisboa: Edições 70, 1993.

BOULEZ, Pierre. Orientations. Cambridge: Harvard University Press, 1986.

BOULEZ, Pierre. Apontamentos de um aprendiz. São Paulo: Perspectiva, 2008.

CASSOTTI, Rosa S. Music, Answerability, and Interpretation in Bakhtin's Circle: reading together M.M.Bakhtin, I. I. Sollertinsky, and M. V. Yudina. In: Festschrift for Nikolay Pan'kov. [S. l.: s. n.], 2011. Disponível em: http://nevmenandr.net/scientia/festschrift/ cassotti.pdf.

CHANG, Chun-Hsien. A study of the technique and function of orchestration in selected works of Claude Debussy: Prélude à l'après-midi d'un faune, Nocturnes, La Mer, and Pelléas et Mélisande. Tesis (Doctors of Arts) - University of Northern Colorado, Greeley, 2002. 
ChARAUDEAU, Patrick; MAINGUENEAU, Dominique. Dicionário de Análise do Discurso. 3. ed. São Paulo: Contexto, 2014. 3ed.

COPE, David. Computer models of musical creativity. Massachusetts: MIT Press, 2005.

COPE, David. Techniques of the contemporary composer. Boston: Cengage Learning, 1997.

DE BONIS, Maurício Funcia. O Miserere de Willy Corrêa de Oliveira: "aporia" e "apodíctica". São Paulo: Annablume, 2010.

DEBUSSY, Claude. Monsieur Croche: e outros ensaios sobre música. Rio de Janeiro: Nova Fronteira, 1989.

DUTILLEUX, Henri. Mystère et Mémoire des Sons. Entretiens avec Claude Glayman. Paris: Actes Sud, 1997.

FARACO, Carlos Alberto. Linguagem e diálogo: as ideias linguísticas do Círculo de Bakhtin. São Paulo: Parábola, 2009.

FERRAROTTI, Franco. Sobre a autonomia do método biográfico. In: NÓVOA, António; FINGER, Mathias. O método (auto)biográfico e a formação. Lisboa: MS/DRHS/CFAP, 1988.

FIORIN, José Luiz. Introdução ao pensamento de Bakhtin. 2. ed. São Paulo: Contexto, 2016.

FORTE, Allen. The structure of atonal music. New Haven: Yale University Press, 1973.

GRIFFTHS, Paul. A música moderna: uma história concisa e ilustrada de Debussy a Boulez. 2. ed. Rio de Janeiro: Zahar, 2011.

GUBAIDULINA, Sofia. An interview with Dorothea Redepenning. In: SCHWARTZ, Elliott; CHILDS, Barney. Contemporary composer on contemporary music. EUA: Da Capo Press, 1998. p. 448-454.

GUIGUE, Didier. Estética da sonoridade: a herança de Debussy na música para piano do século XX. São Paulo: Perspectiva, 2011.

HODEIR, André. As formas da música. Lisboa: Arcádia, 1970.

HOWAT, Roy. Debussy in proportion: a musical analysis. New York: Cambridge University Press, 1986. 
HOWAT, Roy. Debussy, naturaleza y proporcíon. Quodlibet: Revista De Especializacíon Musical, n. 19, p. 118-132, 2001.

KORSYN, Kevin. Beyond privileged contexts: intertextuality, influence, and dialogue. In: COOK, Nicholas; EVERIST, Mark. Rethiking Music. New York: Oxford University Press, 2001.

KOSTKA, Stefan. Materials and techniques of 20th Century Music. 3. ed. New Jersey: Pearson, 2006.

LANNA, Oiliam. Expressões da paródia: polifonia em Carmina Burana. In: MACHADO, I. L. et al. Ensaios em análise do discurso. Belo Horizonte: Fale, UFMG: 2002.

MESSIAEN, Olivier. Technique de mon langage musical. Texte. Paris: A. Leduc, 1944. 2v.

MEYER, Leonard B. Music, the art, and ideas: patterns and predictions in TwentiethCentury Culture. Chicago: University Chicago Press, 1994.

NASCIMENTO, Guilherme. Os sapatos floridos não voam: processos criativos compartilhados entre música, literatura e pintura. São Paulo: Annablume; Belo Horizonte: Fapemig, 2012.

NASSIF, Silvia C.; SCHROEDER, Jorge L. Música como discurso: uma perspectiva a partir da filosofia do Círculo de Bakhtin. Música em Perspectiva, Curitiba, v. 4, n. 2, p. 127-153, 2011.

NASSIF, Silvia C.; SCHROEDER, Jorge L. Apreciação musical para não-musicistas: uma proposta a partir das ideias do Círculo de Bakhtin. Vórtex, Curitiba, v. 7, n. 1, p. 1-28, 2019.

PETRACCA, Ricardo. Música e alteridade: uma abordagem bakhtiniana. Curitiba: Appris, 2018.

SALLES, Cecilia Almeida. Redes da criação: construção da obra de arte. São Paulo: Horizonte, 2014.

SMITH, Jenna. Sofia Gubaidulina's violin concerto Offertorium: theology and music in dialogue. M.A. Théologie en Études Théologiques. Montréal: Université de Montréal, 2010.

SOCHA, Eduardo. O problema da forma na música contemporânea. Artefilosofia, Ouro Preto, n. 4, p. 95-104, jan. 2008. 
VARĖSE, Edgard. Il suono organizzato: scritti sulla musica. Milano: Ricordi: Unicopli, 1985.

VOLOCHÍNOV, Valentin Nikolaevich. Marxismo e filosofia da linguagem: problemas fundamentais do método sociológico na ciência da linguagem. São Paulo: Editora 34, 2013. 